\title{
RESTORATION OF DEGRADED DRYLANDS THROUGH EXCLOSURES ENHANCING WOODY SPECIES DIVERSITY AND SOIL NUTRIENTS IN THE HIGHLANDS OF TIGRAY, NORTHERN ETHIOPIA
}

\author{
Kide M. Gebremedihin, Emiru Birhane*, Tewodros Tadesse, Hailemariam Gbrewahid \\ Mekelle University, Ethiopia \\ *e-mail:emiru.birhane@mu.edu.et,emiru.birhane.hizikiaz@nmbu.edu.et
}

Received: 21.08.2017

\begin{abstract}
Exclusion of grazing animals and tree plantations were among the methods used for the rehabilitation of degraded lands in tropical semiarid areas. Exclosures can foster secondary forest succession by improving soil conditions, attracting seed-dispersal agents and modifying microclimate for understory growth. This paper compares the woody species diversity and soil chemical properties under exclosure with increasing age and grazing land at different slope positions. The study has been conducted in northern Ethiopia from 12 exclosure sites paired each with adjacent grazing land with four treatments replicated three times. In the entire study 216 plots were examined of which 108 were in exclosures and 108 in communal grazing lands. There were four age classes and three slope positions in each of the landuses. Vegetation data were collected using plots measuring $100 \mathrm{~m}^{2}$. Soils for physicochemical properties were collected from the four corners and center of $5 \times 5 \mathrm{~m}$ plots which was inside the $10 \times 10 \mathrm{~m}$ plot. A total of 61 woody plant species belonging to 41 families were recorded. Diversity and species richness were higher in the exclosures than in grazing lands. Among exclosures these parameters were higher in exclosures older than 30 years and at the foot of the slope. Grazing lands, the youngest exclosures and upper elevation gradient recorded lower values. Chemical soil properties were significantly higher in the exclosures, among them in the oldest exclosures and at foot elevation (except for P) than these were in the grazing land, the youngest exclosures and upper parts of slopes respectively. Exclosures are instrumental to improve the woody species diversity and soil chemical properties in the drylands.
\end{abstract}

Key words: chemical soil properties, exclosure, slope position, woody diversity

\section{Introduction}

Land degradation is a widespread problem throughout sub-saharan Africa and its restoration is a challenge for the management of many semi-arid areas (Yayneshet et al., 2009). Extensive deforestation and conversion of natural forests into agricultural land is the main cause of land use change in Ethiopia. The FAO (2007) estimated a deforestation rate of $1410 \mathrm{~km}^{2}$ and the World Bank (2001) found $620 \mathrm{~km}^{2}$ per year. The forest cover of the total area of Ethiopia shrunk from $65 \%$ to $2.2 \%$ (Berry, 2003). $90 \%$ of the total forest reduction was in the highlands, which accounted 5.6\% deforestation. These changes have negatively affected the physical and chemical soil properties as well as the bioavailability of soil nutrients (Solomon et al., 2002). Moreover, the relatively early and extensive deforestation in Ethiopia has eroded the biological diversity to such an extent that some plants are faced with local extinction (Yirdaw, 2001). Land degradation affects the livelihood of the rural population and is a major threat to sustainable land use (Hurni et al., 2005) by enhancing degrada- tion of vegetation cover, soil and nutrient depletion in Ethiopia (Haileslassie et al., 2005).

Forests and the benefits they provide in the form of environmental protection, firewood, food and income have an important and critical role in enabling to secure a stable and adequate food supply. Deforestation and land degradation, however, are reducing the capacity of forests and the land to improve environmental conditions and to provide other benefits (Tadesse, 2001). Furthermore, land degradation exacerbates drought and desertification (Sonneveld $\&$ Keyzer, 2002). Soil erosion has accelerated on the Ethiopian highlands due to deforestation, cultivation of marginal lands, uncontrolled grazing and higher demand for fuelwood by the local communities (Reusing et al., 2000). This has led to a loss of the fertile top soil through erosion and nutrient depletion and resulted in a low plant diversity and agricultural productivity. Farmers can sustainably use their natural resources by introducing proper plant species on the steep slopes and degraded areas to improve soil fertility. Those species can be used as a source of forage 
for livestock and pollen for bees. This would increase the flexibility in the management of land use, fodder and livestock hence enabling households to make a living and diversify sources of livelihood but also address land degradation (Mekonen \& Tesfahunegn, 2011). An improved vegetation cover has assisted to increase soil cover thus decreasing losses of soil moisture through evapotranspiration. Better soil cover has also been vital in facilitating improved water infiltration while decreasing soil erosion and increased litter deposition and carbon sequestration that would upgrade fertility to increase productivity (Wairore et al., 2015). Although soil erosion is prevalent throughout Ethiopia, this problem is particularly severe in Tigray region, which urges the need to implement integrated soil and water conservation measures (Tadesse, 2001).

In response of the land degradation, the government of Ethiopia has initiated a number of projects including soil and water conservation works and establishment of exclosures (Nedessa et al., 2005). Exclosures are areas closed off from the interference of human and domestic animals with the goal of promoting natural regeneration of plants and reducing land degradation of formerly degraded communal grazing lands (Seyoum et al., 2015). Exclosures are usually established in steep, eroded, and degraded areas that have been used for grazing in the past (Descheemaeker et al., 2006). Priority areas for establishing exclosures are normally identified as a joint initiative of local communities and governmental and nongovernmental organisations (Descheemaeker et al., 2006). Exclosure is protecting the degraded land from tree cutting and free grazing of domestic animals (Mengistu et al., 2005). In most cases, for establishing of an exclosure, this area should be abandoned as a result of being unsuitable for human and animal use (Nedessa et al., 2005). According to Lemenih \& Kassa (2014) exclosure involves protecting areas mainly through social fencing from any form of cultivation, cutting trees and shrubs, or grazing by livestock. There are common management interventions in addition to protection that involves planting of seedlings (exotic or indigenous species), aerial seeding and construction of soil and water conservation structures to speed up succession through the modification of microclimatic and soil conditions. As a result, diverse woody and non-woody plant species re-emerge, landscape greenness increases, soil erosion declines, sediment deposition downstream declines and water infiltration and stream discharge increase (Yami et al., 2006; Babulo et al., 2008; Mekuria \& Aynekulu, 2011).

Grazing impacts on soil properties depends on grazing intensity, with moderate grazing of 33 years compared with an ungrazed control, higher values were found for $\mathrm{pH}$, available $\mathrm{P}$, and $\mathrm{Mg}$ in ungrazed sites compared to the grazed ones (Ajorlo et al., 2011). The concentrations of available $\mathrm{P}$, total $\mathrm{N}, \mathrm{Ca}, \mathrm{Mg}$, and $\mathrm{K}$ decreased after 1.5 years of heavy grazing compared with an ungrazed control in a tropical pasture (Ajorlo et al., 2011). In addition, heavy grazing resulted in lower water infiltration (Hiernaux et al., 1999) and higher soil loss (Tadesse \& Penden, 2002) compared with moderately grazed sites. In Tunisia, Jeddi \& Chaieb (2010) documented that 12-year exclosures enhance the total plant cover, dry matter yield, species richness, and contents of organic soil matter, total nitrogen and water infiltration rate compared with continually grazed area. Similarly, Cheng et al. (2011) indicated that 20-year exclusion of livestock grazing significantly increased aboveground and belowground biomass and species richness for five different communities compared with that before exclusion of livestock grazing in a typical steppe of the Loess plateau, northwest China. Additional case studies conducted on exclosures in the central and northern highlands of Ethiopia. So, it was discovered that exclosures had twice more plant species richness and diversity value as compared with communal grazing lands after 22 years of exclosure establishment (Mengistu et al., 2005). And the richness of 13 woody species increased after 8 years of exclosure establishment (Birhane et al., 2006). Also, an increase in organic soil matter, total $\mathrm{N}$ and available $\mathrm{P}$ after 10 years of exclosure establishment was found (Mekuria et al., 2007). Finally, a considerable decrease in soil loss was reported after the establishment of exclosures in communal grazing lands (Descheemaeker et al., 2006; Girmay et al., 2009; Mekuria et al., 2009). Although there have been studies that compared the effect of exclosures on plant diversity and soil with adjacent open grazing lands, most of them are patchy and considering a single area. Studies on the effect of age of exclosures on plant diversity and soil property are few. Therefore this study provides information on the status of woody plant species diversity in 12 exclosures as compared with the adjacent grazing land in the highlands of Tigray, northern Ethiopia. This research was conducted to understand the role of exclosure in restoration of woody plant species diversity and soil chemical properties in two land use types with increasing age of exclosures at different slope gradients. This paper tries to address the following hypotheses: Availability of nutrients are not significantly different between exclosures and adjacent grazing land with increasing age of exclosure and elevation gradient; and: Woody species diversity is not significantly different between exclosures and 
grazing land with increasing age of exclosure and elevation gradient.

\section{Material and Methods}

Description of the Study Area

The study was conducted in the highlands of Tigray region in four zones and four districts representing 12 exclosures and adjacent open grazing sites (Fig. 1). The distance between the exclosure and the adjacent grazing land was in the range of 50 to $100 \mathrm{~m}$. The districts, namely Tahtay Maychew, Degua Temben, Atsibi Wenberta and Enda Mehoni, were $273 \mathrm{~km}, 50 \mathrm{~km}$, 71 and $129 \mathrm{~km}$ away from the capital city of the region, Mekelle respectively.

All sites have a tropical semi-arid climate. The altitude of the study sites ranged from 2232 to 2937 $\mathrm{m}$ a.s.l. (Table 1). The rainy season usually occurs between June and September (Fig. 2), the growing season varying between 90 and 120 days.

Soils of the study sites were classified into four major groups: Luvisols (Alfisols), Regosols (Enti- sols), Cambisols (Inceptisols) and Calcisols (Aridisols) (WRB, 2006), but the sites were dominanted by Luvisols (Alfisols) and Cambisols (Inceptisols). The common woody vegetation species in exclosures and in adjacent grazing lands included Acacia etbaica Schweinf., Acacia seyal (Del.), Becium grandiflorum (Lam.) Pichi-Serm., Euclea racemosa subsp. schimperi (A. DC.) F. White and Maytenus arbutifolia (Hochst. ex. A. Rich) Wilczek (Mekuria, 2010). The livelihood of the households in the study area was a mixed crop livestock farming system. Major land uses in the study area included cultivated lands (between 9 and $33 \%$ of the area), forest-lands (3\% to $58 \%$ ), exclosures ( $3 \%$ to $16 \%$ ), communal grazing lands $(6 \%$ to $39 \%)$ and others $(20 \%$ to $41 \%)(\mathrm{Me}-$ kuria, 2010). There were seven main cultivated crops namely Tef (Eragrostis teff (Zucc.) Trotter), Bread wheat (Triticum aestivum L.), Maize (Zea mays L.), Sorghum (Sorghum bicolor (L.) Moench ), Barly (Hordeum vulgare L.), Faba bean (Vicia faba L.) and Hanfets ${ }^{1}$. The major animal populations were cattle, goats, sheeps, donkeys, camels, mules and horses.

\section{${ }^{1}$ Hanfets is a popular mixture of wheat and barley grown in the highlands of Eritrea and Tigray (Northern Ethiopia).}

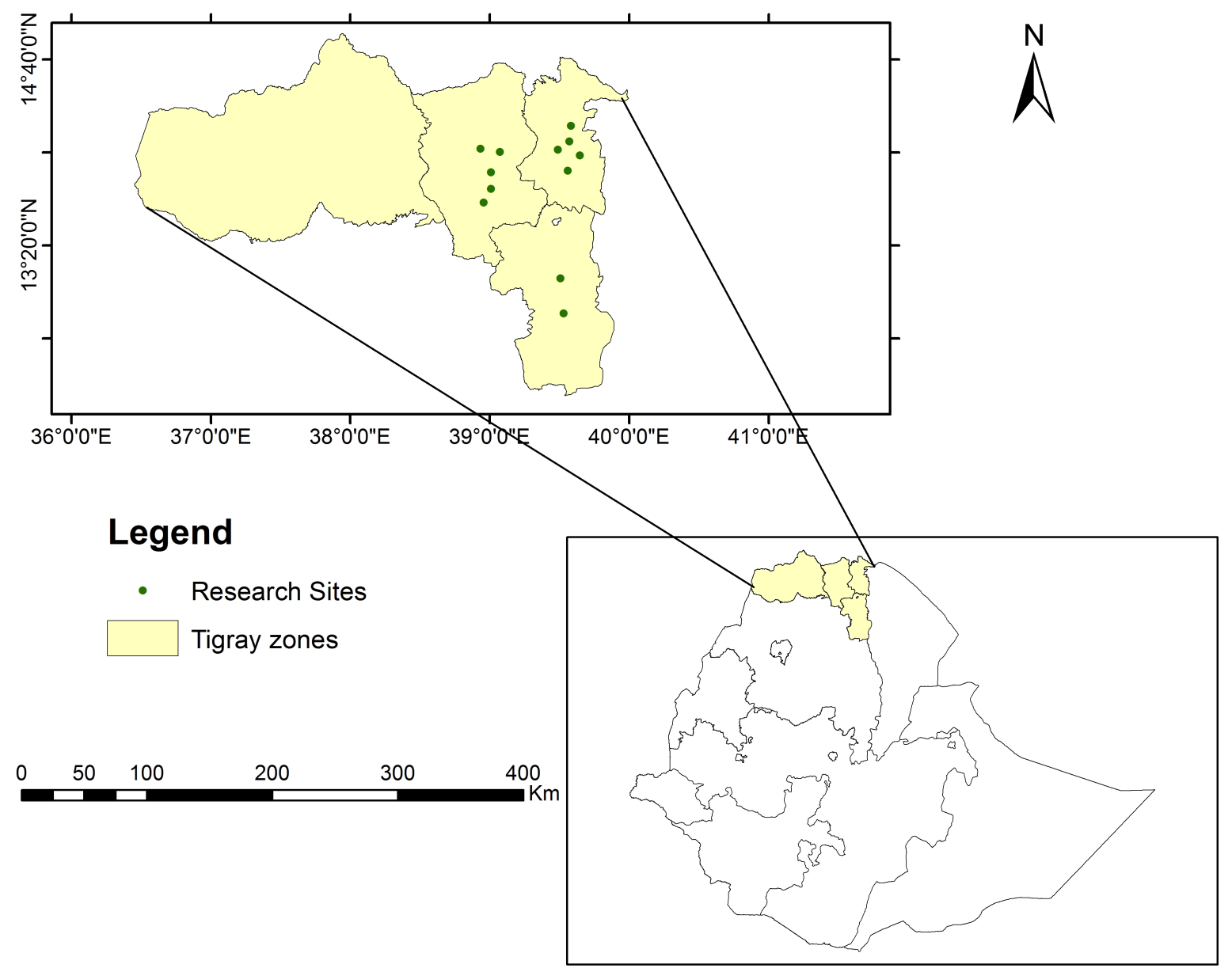

Fig. 1. Location of the study sites in the highlands of Tigray, North Ethiopia. 
Table 1. Specific study site age, altitude and geographic location

\begin{tabular}{|c|c|c|c|c|c|}
\hline Specific site & Zone & District & Age(year) & Altitude (m) & Geographic location \\
\hline Adihintaweinai & East & Atsbi wonberta & $<10$ & $2201-2312$ & $\begin{array}{l}39^{\circ} 038^{\prime} 60^{\prime \prime}-39^{\circ} 050^{\prime} 52^{\prime \prime} \text { East } \\
13^{\circ} 012^{\prime} 75^{\prime \prime}-14^{\circ} 04^{\prime} 41^{\prime \prime} \text { North }\end{array}$ \\
\hline Halla & South east & Degua Tembien & $<10$ & $2232-2937$ & $\begin{array}{l}38^{\circ} 030^{\prime} 17^{\prime \prime}-38^{\circ} 040^{\prime} 57^{\prime \prime} \text { East } \\
13^{\circ} 054^{\prime} 3^{\prime \prime}-14^{\circ} 020^{\prime} 30^{\prime \prime} \text { North }\end{array}$ \\
\hline Melgim & East & Atsbi wonberta & $<10$ & $2264-2343$ & $\begin{array}{l}39^{\circ} 038^{\prime} 60^{\prime \prime}-39^{\circ} 050^{\prime} 52^{\prime \prime} \text { East } \\
13^{\circ} 012^{\prime} 75^{\prime \prime}-14^{\circ} 04^{\prime} 41^{\prime \prime} \text { North }\end{array}$ \\
\hline Endagebriel & East & Atsbi wonberta & $10-20$ & $2248-2351$ & $\begin{array}{l}39^{\circ} 038^{\prime} 60^{\prime \prime}-39^{\circ} 050^{\prime} 52^{\prime \prime} \text { East } \\
13^{\circ} 012^{\prime} 75^{\prime \prime}-14^{\circ} 04^{\prime} 41^{\prime \prime} \text { North }\end{array}$ \\
\hline Gurzoemni & Central & Tahtay Maichew & $10-20$ & $2244-2322$ & $\begin{array}{l}38^{\circ} 030^{\prime} 17^{\prime \prime}-38^{\circ} 040^{\prime} 57^{\prime \prime} \text { East } \\
13^{\circ} 054^{\prime} 3^{\prime \prime}-14^{\circ} 020^{\prime} 30^{\prime \prime} \text { North }\end{array}$ \\
\hline Mezewle & East & Atsbi wonberta & $10-20$ & $2325-2411$ & $\begin{array}{l}39^{\circ} 038^{\prime} 60^{\prime \prime}-39^{\circ} 050^{\prime} 52^{\prime \prime} \text { East } \\
13^{\circ} 054^{\prime} 3^{\prime \prime}-14^{\circ} 020^{\prime} 30^{\prime \prime} \text { North }\end{array}$ \\
\hline Adikolakul & South east & Degua Tembien & $20-30$ & $2180-2214$ & $\begin{array}{l}38^{\circ} 030^{\prime} 17^{\prime \prime}-38^{\circ} 040^{\prime} 57^{\prime \prime} \text { East } \\
13^{\circ} 054^{\prime} 3^{\prime \prime}-14^{\circ} 020^{\prime} 30^{\prime \prime} \text { North }\end{array}$ \\
\hline Suhulkoma & East & Atsbi wonberta & $20-30$ & $2295-2347$ & $\begin{array}{l}39^{\circ} 038^{\prime} 60^{\prime \prime}-39^{\circ} 050^{\prime} 52^{\prime \prime} \text { East } \\
13^{\circ} 012^{\prime} 75^{\prime \prime}-14^{\circ} 04^{\prime} 41^{\prime \prime} \text { North }\end{array}$ \\
\hline Wereriba & South east & Doguetembien & $20-30$ & $2200-2358$ & $\begin{array}{l}13^{\circ} 016^{\prime} 23^{\prime \prime}-13^{\circ} 047^{\prime} 44^{\prime \prime} \text { East } \\
39^{\circ} 03^{\prime} 17^{\prime \prime}-39^{\circ} 024^{\prime} 48^{\prime \prime} \text { North }\end{array}$ \\
\hline Gratselim & South east & Degua Tembien & $30-40$ & $2369-2458$ & $\begin{array}{l}38^{\circ} 030^{\prime} 17^{\prime \prime}-38^{\circ} 040^{\prime} 57^{\prime \prime} \text { East } \\
13^{\circ} 054^{\prime} 3^{\prime \prime}-14^{\circ} 020^{\prime} 30^{\prime \prime} \text { North }\end{array}$ \\
\hline Kerenadidemsash & South & Endamekoni & $30-40$ & 2314-2419 & $\begin{array}{l}39^{\circ} 016^{\prime} 52^{\prime \prime}-39^{\circ} 035^{\prime} 31^{\prime \prime} \text { East } \\
12^{\circ} 038^{\prime} 4^{\prime \prime}-12^{\circ} 051^{\prime} 39^{\prime \prime} \text { North }\end{array}$ \\
\hline Maibiati & South east & Degua Tembien & $30-40$ & $2358-2429$ & $\begin{array}{l}38^{\circ} 030^{\prime} 17^{\prime \prime}-38^{\circ} 040^{\prime} 57^{\prime \prime} \text { East } \\
13^{\circ} 054^{\prime} 3^{\prime \prime}-14^{\circ} 020^{\prime} 30^{\prime \prime} \text { North }\end{array}$ \\
\hline
\end{tabular}
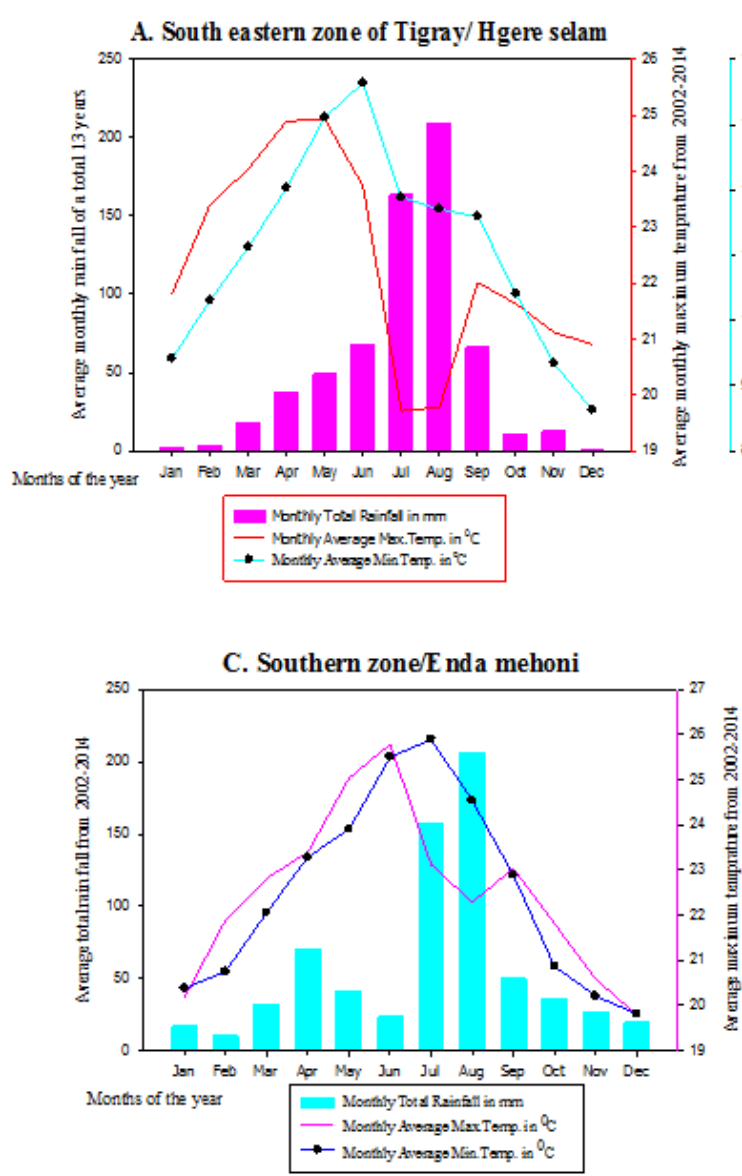

B. Central zone of Tigray/ Tahtay maychew
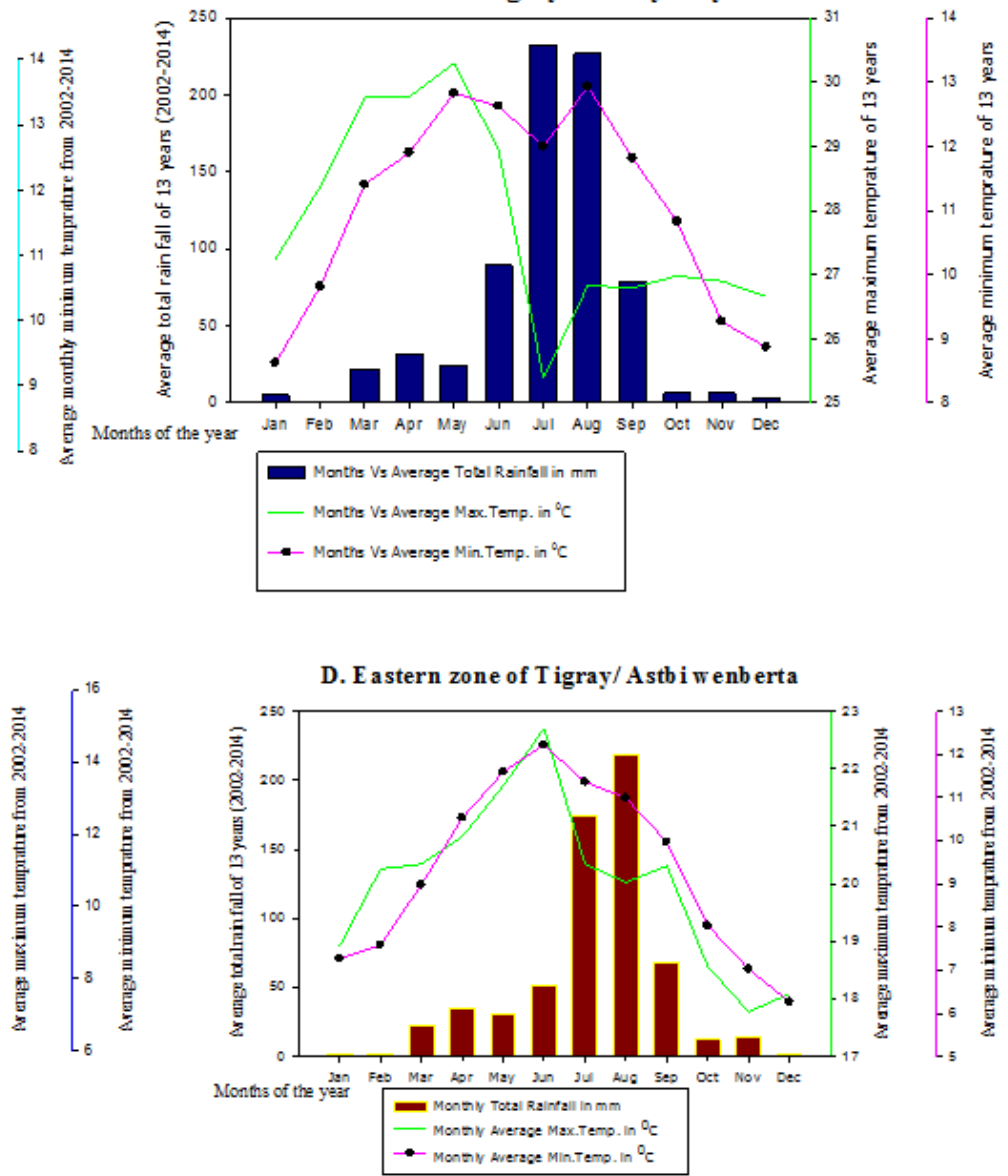

D. E astern zone of T igray/Astbi w enberta

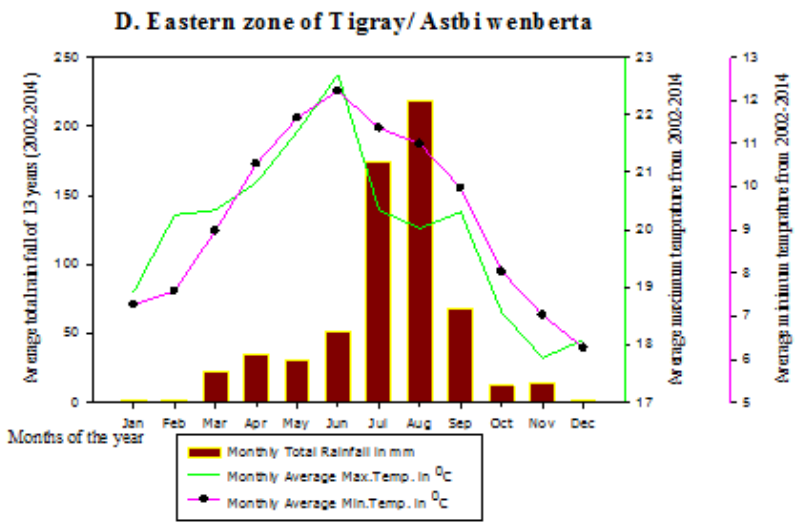

Fig. 2. Monthly average temperature and rain fall of the study area (A, B, C and D) from 2002 to 2014 (EMA, 2014). 
Exclosure is a method of rehabilitating land by protecting an area from the interference of animals and human encroachment for a limited period of time, depending on site capacity and vegetation re-establishment (Seyoum et al., 2015). The grazing lands are areas open for continuously grazing by livestock. The exclosures are mainly covered by trees, shrubs and the ground by grass. The life forms of woody plants in the exclosures were $35.1 \%$ trees and $39.73 \%$ were shrubs, while the rest $(25.17 \%)$ were woody herbs and climbers. The life forms in the open grazing lands were $83.37 \%$ shrubs and $5.7 \%$ were trees, while the rest $(10.93 \%)$ were woody herbs; shrubs significantly outnumbered the trees in the exclosures. The abundance of the naturally regenerated woody plants in the exclosures was $91.03 \%$ while $8.9 \%$ was found artificially planted but no planted seedling was observed in the open grazing lands. The abundant species in the exclosures were composed of naturally regenerated species.

\section{Experimental layout and design}

There were 12 exclosure sites having adjacent grazing land, divided into four age classes and three slope gradients to study the age, slope and land use effect on woody species diversity and chemical soil properties. The first age group had less than ten years old exclosures with triplicate sites (Halla, Meligim and Gidimihantaweynay), the second age group was 10 to 20 years old exclosures with triplicate sites (Gurzoemni, Mezewle and Endagebriel), and the third age group had 20 to 30 years old exclosures with triplicate sites (Addikolakul, Wereriba and Shul-koma). The fourth group had more than 30 years old exclosures with triplicate sites (Maybe'ati, Wadrat and Endaarbaetuenssat).

The role of the exclosure on the soil fertility and the diversity of woody plant species were studied by taking soil and the identitiy of woody plant species and number of plants, under the different ages of paired exclosures and adjacent grazing lands. The experiment was composed of 12 experimental units with four treatments replicated three times. In the entire study 216 plots $(12 \times 3$ small plots $\times 3$ slope positions $\times 2$ pair exclosures and adjacent grazing lands) were examined of which 108 were in exclosures and 108 in communal grazing lands. In each exclosure and grazing land randomly established three transects spaced at a minimum distance of 75 $\mathrm{m}$ (Fig. 3). The number of transects were based on vegetation density, spatial heterogeneity of vegetation, and area of the site. To avoid edge effects, the first transect were laid $30-50 \mathrm{~m}$ inside the exclosures and grazing lands. Transects were parallel to each other and to the topography of the landscape. In each transect, three slope positions were delineated and a sampling plot measuring $10 \times 10 \mathrm{~m}$ was established. In each plot, $5 \times 5 \mathrm{~m}$ subplots for physical and chemical soil analysis were developed (Fig. 3 ). Each of the study sites were divided into 3 slope gradients: upper slope (US), middle slope (MS) and foot slope (FS). The US position is the uppermost portion of each study site and it can receive little or no overland flow but may contribute runoff to down slope areas. The MS position receives overland flow from the upper slope and contributes runoff to the FS. The FS represents the lowest part of each study site and receives overland flow from both mid and upper slopes.

\section{Plant and soil sampling methods}

Plant and soil samples were collected from October 2013 to January 2014 for a total of four months from four types of exclosures and adjacent surrounding grazed land. All woody plants were sampled for diversity in $10 \times 10 \mathrm{~m}$ quadrates $\left(100 \mathrm{~m}^{2}\right)$ for trees and shrubs from both sites. The plants were identified in the field and verified using reference books such as BekeleTesemma (2007), Hedberg et al. (2003), Hedberg \& Edwards (1989), and Edwards et al. (1995, 2000). All woody plants (trees and shrubs) found in each plot were counted. Each plant height, diameter at breast height (DBH), diameter at stump height (DSH) and plant number were recorded. The abundance (total number of woody species in a given area), density (number of individuals of a species in an area per ha) and frequency (number of times a species recorded in a given number of plots) of woody species were calculated.

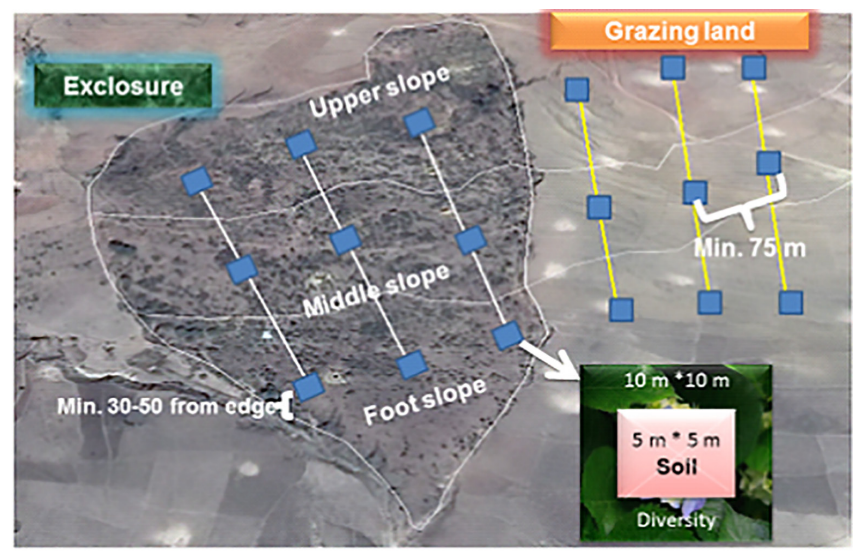

Fig. 3. Experimental designs of the soil and vegetation sampling in one replicate of an exclosure with its paired communal grazing land. 
Soil samples were collected from $5 \times 5 \mathrm{~m}$ subplots nested within the 10 Ч $10 \mathrm{~m}$ at the centre of the main plots. A total of 216 soil samples were collected. The soil samples from each plot were taken from the four corners and the centre of a square plot at $50 \mathrm{~cm}$ soil depths following an «X» pattern of the main plot to form one composite sample in order to determine organic carbon, $\mathrm{pH}, \mathrm{EC}, \mathrm{N} \mathrm{K}$ and $\mathrm{P}$ of the soil in exclosures and adjacent grazing lands. The five soil samples measured $300 \mathrm{~g}$, each collected from $50 \mathrm{~m}$ depth in each $25 \mathrm{~m}^{2}$ plots, were mixed and form $1500 \mathrm{~g}$ in total and make a single composite sample to represent the sample plot. From the composite sample $1 \mathrm{~kg}$ soil was taken and put into plastic bags, secured, labeled and brought to the soil laboratory. Soil samples were analysed for $\mathrm{pH}$ and electrical conductivity on 1:2.5, soil: water suspension method. The organic matter was analysed using the Walkley-Black method (Van Ranst et al., 1999), the total nitrogen content by the Kjeldahl method (Bremmery \& Mulvaney, 1982). The available potassium and texture were analysed with flame spectrophotometer and hydrometer method (Gee \& Bauder, 1982). The available P was determined using the Olson method (Olsen \& Sommers, 1982).

\section{Statistical analyses}

The number and abundance of the woody species diversity (Dominance (D), Shannon (H), Simpson (1-D), Evenness $\left(E^{\wedge} \mathrm{H} / \mathrm{S}\right)$ with ages of the exclosures, adjacent grazing land and slope positions were analysed using the PAST software package, version 1.91. The differences in soil parameters between an exclosure and its adjacent communal grazing land at different age groups and landscape position were assessed using ANOVA with Tukey HSD test after checking normality test. Statistical package for social sciences (SPSS) version 20 was used to analyse the chemical soil properties.

Results and Discussion

Woody plant species composition in exclosures and grazing lands at different age and slope gradient

In total there were noted 61 woody plant species, representing 41 families, and 51\% were trees and 49\% were shrubs (Appendix 1). Among these plant species $8 \%$ were planted while the rest, $92 \%$ plants, were naturally grown. In the exclosures there were 60 plant species and 40 plant families, of which $53 \%$ were trees and $47 \%$ shrubs, while the grazing land had 28 plant species that belongs to 21 plant families (Appendix 2 and 3 ). So, from the total species found in the study area 32 species were only found in exclosures. This study is in agreement with research done in exclosures and open grazing land in Tigray where 39 plants were found in both exclosures and open grazing land, of which 31 plants were naturally found and 8 were planted (Birhane, 2002). The same author found 27 plant species and 18 families in exclosures, of those $37 \%$ trees and $52 \%$ shrubs, but the open grazing land had 14 plant species of 12 families and $50 \%$ were either trees or shrubs. Another study found 56 woody trees and shrubs belonging to 28 families in both disturbed and undisturbed areas, the undisturbed areas had 47 woody species belonging to 26 families and 42 woody species belonging to 24 families in disturbed areas (Dejenie, 2011). The foot slope had 56 plants representing 39 families, 52\% trees and $48 \%$ shrubs (Appendix 4), while the middle slope had 49 plant species of 32 families, 51\% trees and 49\% shrubs (Appendix 5). The upper slope had 42 plant species of 28 families; from those $48 \%$ were trees and 52\% were shrubs (Appendix 6). Exclosures less than 10 years old had 18 plant species of 12 families, of which $67 \%$ were shrubs (Appendix 7), at the same time exclosures with an age between 10 and 20 years old had 23 plant species representing 12 families and 57\% were trees (Appendix 8), while exclosures with an age between 20 and 30 years old had 36 plant species of 27 families and 53\% were shrubs (Appendix 9). Exclosures older than 30 years had 49 plant species of 36 families, with $51 \%$ trees and $49 \%$ shrubs and had a higher species richness than in exclosures of the other three age groups (Appendix 10).

Woody plant species diversity in exclosures and grazing lands at different age and slope gradient

In the study area 61 plant species from 41 plant families were found, which is more than the result found in exclosures and open areas in eastern Tigray (Birhane, 2002). The exclosures had a higher diversity, high species richness and these were less evenly distributed, whereas grazing land had a low species richness and the species were evenly distributed (Table 2). 
The plant density and abundance of plants were higher in exclosures and lower in grazing land (Appendix 2 and 3), which is in agreement with exclosures in eastern Tigray (Birhane, 2002). The exclosures in this study had a higher diversity than the exclosures in central and northern Ethiopian (Mengistu et al., 2005). Undisturbed sites have a higher diversity than disturbed sites in the Awash National Park in central Ethiopia (Molla et al., 2009). The establishment of exclosures improved the composition, density, richness, and diversity of woody species in comparison to open adjacent sites.

Woody species were substantially richer in exclosures than in open areas, indicating the importance of exclosures for the conservation of biological diversity (Mengistu et al., 2005). Diversity is the most widely used criterion to assess the conservation potential and ecological value of a site (Magurran, 2004). Moreover, it is an important element in resource management planning. This especially holds true for rare and endangered species (Jama \& Zeila, 2005). Exclosures are supposed to contribute to the conservation of biological diversity. The higher Shannon diversity indices in the exclosures indicate a higher species diversity in the exclosures than in the open site (Getachew, 2014). The relatively high diversity values of exclosures compared with that of the open areas in turn indicates the importance of exclosure practices for the conservation of genetic resources of the woody species, particularly rare and unique species that are under heavy threat of extinction. Old age exclosures had a higher plants diversity, high species richness and these were also evenly distributed (Table 2), which is in line with Mekuria (2013), who indicated that the oldest exclosures had a higher diversity and species richness than the youngest exclosures.
There was a significant difference in plant diversity along the slope gradients $(p<0.05)$. The foot slope of the mountain had a high diversity and plants were evenly distributed. The diversity was higher for the foot slopes followed by the middle and upper slope. This result contradicts to Mekuria (2013), who found a higher diversity at the upper slope.

Woody plants frequency, abundance and density in exclosures and grazing lands at different age and slope gradient

In the study area Euclea racemosa L., Maytenus arbutifolia (Lam.) Exell, Becium grandiflorum (Lam.) Pic. Serm., Acacia seyal Delile and Juniperus procera Hochst. ex Endl. were the most frequently found, while Clutia lanceolata Forssk., Diplostigma canescens K. Schum., Justicia schimperiana (Hochst. ex Nees) T. Anderson, Morus alba L., Berberis holstii Engl. and Pittosporum viridiflorum Sims were found the least frequently. Individuals of species from the plant families Fabaceae, Celastraceae, Ebenaceae and Lamiaceae were found frequently, while Acanthaceae, Asclepiadaceae and Pittosporaceae had a low frequency (Appendix 1-10). Dodonaea angustifolia L. f., Becium grandiflorum, Euclea racemosa and Acacia etbaica Schweinf. had a higher abundance and density of individuals while Clutia lanceolata, Justicia schimperiana and Morus alba had a low abundance and density. Exclosures of the age group more than 30 years old and the foot slope had a higher plant frequency, abundance and density while grazing land of the age group less than 10 years old and upper elevation recorded the lowest (Table 3). The density of woody plants in central and northern Ethiopia were found higher in exclosures, while lower in open area (Mengistu et al., 2005).

Table 2. Diversity of plants in exclosures and adjacent grazing lands with increasing age of exclosures and slope gradient

\begin{tabular}{llcccccc}
\hline & & Taxa_S & Individuals & Dominance_D & Simpson1-D & Shannon_H & Evenness_e $\mathrm{e}^{\wedge} \mathrm{H}$ \\
\hline \multirow{2}{*}{ Land use } & Exclosure & 60 & 4589 & 0.1022 & 0.8978 & 2.847 & 0.2872 \\
& Grazing & 28 & 1425 & 0.1193 & 0.8807 & 2.512 & 0.4402 \\
\hline \multirow{5}{*}{ Age (year) } & $\mathbf{1 0}$ & 18 & 1066 & 0.1952 & 0.8048 & 2.033 & 0.4243 \\
& $10-20$ & 23 & 1764 & 0.1757 & 0.8243 & 2.208 & 0.3954 \\
& $20-30$ & 37 & 1469 & 0.1269 & 0.8731 & 2.501 & 0.3297 \\
\multirow{3}{*}{ Slope position } & Mot & 56 & 2255 & 0.07922 & 0.9208 & 3.036 & 0.3718 \\
& Middle & 49 & 1967 & 0.09916 & 0.9008 & 2.773 & 0.3267 \\
& Upper & 42 & 1776 & 0.1087 & 0.8913 & 2.654 & 0.3383 \\
\hline
\end{tabular}


Table 3. Woody plants frequency, abundance and density in exclosures and adjacent grazing land with increasing with age of exclosures and slope position

\begin{tabular}{|c|c|c|c|c|c|}
\hline Factors & Parameters & Frequency (FR) & Percent $(\%)$ & Abundance (AB) & Density (DE) \\
\hline \multirow{2}{*}{ Land use } & Exclosure & 699 & 100 & 4589 & 4267.8 \\
\hline & Open area & 292 & 100 & 1425 & 1325.3 \\
\hline \multirow{4}{*}{ Age grouops } & $>30$ & 328 & 100 & 1702 & 3233.8 \\
\hline & $20-30$ & 266 & 100 & 1466 & 2785.4 \\
\hline & $10-20$ & 231 & 100 & 1764 & 3351.6 \\
\hline & $<10$ & 166 & 100 & 1066 & 2025.4 \\
\hline \multirow{3}{*}{ Slope } & Foot & 408 & 100 & 2255 & 3157.0 \\
\hline & Middle & 317 & 100 & 1967 & 2753.8 \\
\hline & Upper & 266 & 100 & 1776 & 2486.4 \\
\hline
\end{tabular}

Availability of nutrients in exclosures and grazing lands with increasing age of exclosures and elevation gradient

The chemical soil properties of exclosures were significantly more favourable for plant development than of grazing land (Table 4). This result is supported by Mekuria (2010). Grazing impact on soil properties depends on the grazing intensity. An ungrazed site of 33 years old had higher values of $\mathrm{pH}$, available $\mathrm{P}$ and $\mathrm{Mg}$ compared to a moderately grazed site (Ajorlo et al., 2011) and the concentrations of available $\mathrm{P}$, total $\mathrm{N}, \mathrm{Ca}, \mathrm{Mg}$, and $\mathrm{K}$ decreased after 1.5 years of heavy grazing, compared with an ungrazed control in a tropical pasture. The texture had no significant difference in all age groups and elevation except among exclosures and adjacent grazing land. The chemical soil properties at older age exclosures had values of $\mathrm{pH}, \mathrm{EC}, \mathrm{P}, \mathrm{N}, \mathrm{K}, \mathrm{OC}, \mathrm{OM}$ better for plant development than the three young age groups of exclosures. The availability of chemical soil properties decreased with decreasing age of the exclosures. This shows a better result for plant development than by Minal \& Anil (2012), who noted the following data: $\mathrm{pH}(5.1-6.1), \mathrm{EC}\left(\mathrm{dsm}^{-1}\right)(0.22-0.28)$, OC $\%(0.32-0.04)$ and $\mathrm{P}\left(\mathrm{mg} \times \mathrm{kg}^{-1}\right)(4.2-7.7)$. The foot of a slope had better chemical soil properties than the middle and upper slope and EC was significantly higher at the foot slope and followed by middle and upper slope respectively which is in agreement with Mekuria (2010), who found higher nutrients at the foot slope. Except for EC the middle and upper slopes had no significantly different values $(p>0.05)$.

\section{Conclusions}

Diversity and species richness were higher in the exclosures than in grazing lands. Among exclosures these parameters were higher in exclosures older than 30 years and at the foot of the slope. The grazing land, the youngest exclosures and the upper slope had a lower species richness and diversity. The contents of chemical soil properties showed a significant difference and were the highest in the oldest exclosures and at the foot slope. The open grazing land, the youngest exclosures and the upper slope showed poor chemical properties. Exclosures can have multiple importances in improving soil and plants diversity. Exclosures have environmental, social and economic benefits to the local communities. Even though the exclosure management regime has a potential to rehabilitate the degraded areas, integrating soil and water conservation measures and indigenous

Table 4. Soil properties in exclosures and adjacent grazing lands with increasing age of exclosures and elevation gradient

\begin{tabular}{llccccccc}
\hline & & Mean $\mathrm{pH}$ & Mean EC & Mean P & Mean K & Mean \% N & Mean \% OC & Mean \% OM \\
\hline \multirow{2}{*}{ Land uses } & Exclosure & $7.752 \pm 0.035 \mathrm{a}$ & $15.898 \pm 0.382 \mathrm{a}$ & $9.143 \pm 0.455 \mathrm{a}$ & $8.80 \pm 0.296 \mathrm{a}$ & $0.565 \pm 0.010 \mathrm{a}$ & $1.727 \pm 0.057 \mathrm{a}$ & $2.977 \pm 0.099 \mathrm{a}$ \\
& $\mathrm{Gl}$ & $7.295 \pm 0.035 \mathrm{~b}$ & $9.424 \pm 0.382 \mathrm{~b}$ & $2.918 \pm 0.455 \mathrm{~b}$ & $3.748 \pm 0.295 \mathrm{~b}$ & $0.275 \pm 0.010 \mathrm{~b}$ & $0.339 \pm 0.057 \mathrm{~b}$ & $0.584 \pm 0.099 \mathrm{~b}$ \\
\hline \multirow{3}{*}{ Age groups } & 10 & $7.240 \pm 0.053 \mathrm{c}$ & $10.402 \pm 0.646 \mathrm{~b}$ & $2.214 \pm 0.676 \mathrm{c}$ & $3.857 \pm 0.496 \mathrm{c}$ & $0.345 \pm 0.023 \mathrm{~b}$ & $0.442 \pm 0.113 \mathrm{c}$ & $0.762 \pm 0.196 \mathrm{c}$ \\
& $10-20$ & $7.492 \pm 0.053 \mathrm{~b}$ & $11.989 \pm 0.646 \mathrm{~b}$ & $5.747 \pm 0.676 \mathrm{~b}$ & $6.146 \pm 0.496 \mathrm{~b}$ & $0.403 \pm 0.023 \mathrm{~b}$ & $0.952 \pm 0.113 \mathrm{~b}$ & $1.642 \pm 0.196 \mathrm{~b}$ \\
& $20-30$ & $7.606 \pm 0.053 \mathrm{ab}$ & $12.414 \pm 0.646 \mathrm{~b}$ & $6.169 \pm 0.676 \mathrm{~b}$ & $6.71 \pm 0.496 \mathrm{ab}$ & $0.428 \pm 0.023 \mathrm{ab}$ & $1.250 \pm 0.113 \mathrm{ab}$ & $2.154 \pm 0.196 \mathrm{ab}$ \\
& $>30$ & $7.757 \pm 0.053 \mathrm{a}$ & $15.838 \pm 0.646 \mathrm{a}$ & $9.993 \pm 0.676 \mathrm{a}$ & $8.37 \pm 0.501 \mathrm{a}$ & $0.503 \pm 0.023 \mathrm{a}$ & $1.487 \pm 0.113 \mathrm{a}$ & $2.564 \pm 0.196 \mathrm{a}$ \\
\hline \multirow{3}{*}{ Elevation } & Foot & $7.718 \pm 0.048 \mathrm{a}$ & $14.281 \pm 0.588 \mathrm{a}$ & $7.205 \pm 0.661 \mathrm{a}$ & $6.664 \pm 0.471 \mathrm{a}$ & $0.478 \pm 0.020 \mathrm{a}$ & $1.221 \pm 0.107 \mathrm{a}$ & $2.106 \pm 0.184 \mathrm{a}$ \\
& Middle & $7.506 \pm 0.048 \mathrm{~b}$ & $12.450 \pm 0.588 \mathrm{ab}$ & $5.759 \pm 0.661 \mathrm{a}$ & $6.396 \pm 0.467 \mathrm{a}$ & $0.409 \pm 0.020 \mathrm{~b}$ & $1.035 \pm 0.107 \mathrm{ab}$ & $1.784 \pm 0.184 \mathrm{ab}$ \\
& Upper & $7.348 \pm 0.048 \mathrm{~b}$ & $11.252 \pm 0.588 \mathrm{c}$ & $5.128 \pm 0.661 \mathrm{a}$ & $5.733 \pm 0.467 \mathrm{a}$ & $0.372 \pm 0.020 \mathrm{~b}$ & $0.842 \pm 0.107 \mathrm{~b}$ & $1.451 \pm 0.184 \mathrm{~b}$ \\
\hline
\end{tabular}

Means in the same column followed by same letter do not differ significantly at $\mathrm{P}<0.05$, mean value three replications $\pm \mathrm{SE}$, with units of Av.P $=$ ppm, Av.K $=\mathrm{pmm}, \mathrm{EC}=\mathrm{ms} / \mathrm{m}, \mathrm{Gl}=$ Grazing land 
enrichment planting in the exclosures could be a better method of management to accelerate the rehabilitation process of the exclosures and to increase the diversity and density of woody plant species in the exclosures. Additional research is needed to establish the interactive relationships among soil properties, soil fertilities, survival rate and growth rate of woody plant species in the exclosures.

\section{References}

Ajorlo M., Abdullah R., Hanif A.H.M., Halim R.A., Yusoff M.K. 2011. Impacts of livestock grazing on selected soil chemical properties in intensively managed pastures of Peninsular Malaysia. Pertanika Journal of Tropical Agricultural Science 34: 109-121.

Bekele-Tesemma A. 2007. Useful trees and shrubs of Ethiopia: Identification, Propagation and Management for 17 Agroclimatic Zones. Nairobi: RELMA. 550 p.

Berry L. 2003. Land degradation in Ethiopia: Its extent and impact. In: L. Berry, J. Olson, D. Campbell (Eds.): Assessing the extent, cost and impact of land degradation at the national level: Findings and lessons learned from seven pilot case studies. Washingon, DC: World Bank. P. 29-51.

Babulo B., Muys B., Nega F., Tollens E., Nyssen J., Deckers J., Mathijs E. 2008. Household livelihood strategies and forest dependence in the highlands of Tigray, Northern Ethiopia. Agricultural Systems 98: 147-155. DOI: 10.1016/j.agsy.2008.06.001

Birhane E., Teketay D., Barklund P. 2006. Actual and potential contribution of exclosures to enhance biodiversity of woody species in the drylands of Eastern Tigray. Journal of the Drylands 1(2): 134-147.

Birhane E. 2002. Actual and Potential Contributions of Enclosures to Enhance Biodiversity in Drylands of Eastern Tigray, with Particular Emphasis on Woody Plants. Upsala, Sweden: Swedish University of Agricultural Sciences. $63 \mathrm{p}$.

Bremmer J.M., Mulvaney C.S. 1982. Nitrogen total. In: A.L. Page (Ed.): Methods of Soil Analysis, Part 2 Chemical and Microbiological Properties, №9. Madison, WI, USA: ASA Monograph. P. 595-624.

Cheng J., Wu G.L., Zhao L.P., Li Y., Li W., Cheng J.M. 2011. Cumulative effects of 20-year exclusion of livestock grazing on above and belowground biomass of typical steppe communities in arid areas of the Loess Plateau, China. Plant, Soil and Environment 57: 40-44.

Dejenie A. 2011. Impact of Resettlement on Woody Plant Species and Local Livelihood: The Case of Guraferda Woreda in Bench Maji Zone, South Western, Ethiopia. PhD Thesis. Addis Ababa, Ethiopia. 98 p.

Descheemaeker K., Muys B., Nyssen J., Poesen J., Raes D., Haile M., Deckers J. 2006. Litter production and or- ganic matter accumulation in exclosures of the Tigray highlands, Ethiopia. Forest Ecology and Management 233: 21-25. DOI: 10.1016/j.foreco.2006.05.061

Edwards S., Tadesse M., Hedberg I. (Eds.). 1995. Flora of Ethiopia and Eritrea. Vol. 2, Part 2: Canellaceae to Euphorbiaceae. Ethiopia: Addis Ababa University Press. 456 p.

Edwards E., Tadesse M., Demissew S., Hedberg I. (Eds.). 2000. Flora of Ethiopia \& Eritrea. Vol. 2, Part 1: Magnoliaceae to Flacourtiaceae. Ethiopia: Addis Ababa University Press. 532 p.

EMA. 2014. Ethiopian Meteorological service agency Report of Ethiopian meteorological service agency from the respective areas. Addis Ababa, Ethiopia.

FAO. 2007. Enhancing Stakeholder Participation in National Forest Programmes. Rome, Italy: Forestry Policy Brief.

Gee G.W., Bauder J.W. 1982. Particle size analysis. In: A. Klute (Ed.): Methods of Soil Analysis, Part 1 Physical and Mineralogical Methods, №9. Madison, WI, USA: ASA Monograph. P. 383-411.

Getachew M. 2014. Vegetation Dynamics of Area Enclosure Practices: A Case of Gonder Zuria District, Amhara Region, Ethiopia. Journal of Natural Sciences Research 4(7): 75-82.

Girmay G., Singh B.R., Nyssen J., Borrosen T. 2009. Runoff and sedimentassociated nutrient losses under different land uses in Tigray, Northern Ethiopia. Journal of Hydrology 376: 70-80. DOI: 10.1016/j.jhydrol.2009.07.066

Haileslassie A., Priess J., Veldkamp E., Teketay D., Lensschen J.P. 2005. Assessment of soil nutrient depletion and its spatial variability on smallholders' mixed farming systems in Ethiopia using partial versus full nutrient balances. Agriculture Ecosystem and Environment 108(1): 1-16. DOI: 10.1016/j.agee.2004.12.010

Hedberg I. \& Edwards S. (Eds). 1989. Flora of Ethiopia. Vol. 3: Pittosporaceae to Araliaceae. Ethiopia: Addis Ababa University Press. 670 p.

Hedberg I., Edwards S., Nemomissa S. (Eds.). 2003. Flora of Ethiopia and Eritrea. Vol. 4, Part 1: Apiaceae to Dipsacaceae. Ethiopia: Addis Ababa University Press. 352 p.

Hiernaux P., Bielders C.L., Valentin C., Bationo A., Fernandez-Rivera S. 1999. Effects of livestock grazing on physical and chemical properties of sandy soils in Sahelian rangelands. Journal of Arid Environments 41: 231-245. DOI: 10.1006/jare.1998.0475

Hurni H., Kebede T., Gete Z. 2005. The implications of changes in population, land use, and land management for surface runoff in the Upper Nile Basin area of Ethiopia. Mountain Research and Development 25: 145-149. DOI: 10.1659/0276-4741(2005)025[0147:TIOCIP]2.0.CO;2

Jama B., Zeila A. 2005. Agroforestry in the drylands of eastern Africa: a call to action. ICRAF Working Paper№1. Nairobi: World Agroforestry Centre. 29 p.

Jeddi K., Chaieb M. 2010. Changes in soil properties and vegetation following livestock grazing exclusion in degraded arid environments of South Tunisia. Flora 
- Morphology, Distribution, Functional Ecology of Plants 205: 184-189. DOI: 10.1016/j.flora.2009.03.002

Lemenih M., Kassa H. 2014. Re-Greening Ethiopia: History, Challenges and Lessons. Forests 5: 1896-1909. DOI: $10.3390 / \mathrm{f} 5081896$

Magurran A.E. 2004. Measuring biological diversity. London: Blackwell Publishing. 256 p.

Mekuria W. 2010. Effectiveness of Exclosures to Restore Ecosystem Carbon Stock and Vegetation in the Highlands of Tigray, Northern Ethiopia. PhD thesis. Göttingen: University of Göttingen.

Mekuria W. 2013. Changes in Regulating Ecosystem Services following establishing Exclosures on Communal Grazing lands in Ethiopia. Journal of Ecosystems 2013 (2013): 1-12. DOI: 10.1155/2013/860736

Mekuria W., Aynekulu E. 2011. Exclosure land management for restoration of the soil in degraded communal grazing lands in northern Ethiopia. Land Degradation and Development 246(6): 528-538. DOI: 10.1002/ldr. 1146

Mekuria W., Edzo V., Haile M., Gebrehiwot K., Bart M., Jan N. 2009. Effectiveness of exclosures to control soil erosion and local community perception on soil erosion in Tigray, Ethiopia. African Journal of Agricultural Research 4(4): 365-377.

Mekuria W., Veldkamp E., Mitiku H., Nyssem J., Muys B., Kindeya G. 2007. Effectiveness of exclosures to restore degraded soils as a result of overgrazing in Tigray, Ethiopia. Journal of Arid Environments 69: 270-284. DOI: 10.1016/j.jaridenv.2006.10.009

Mekonen K., Tesfahunegn G.B. 2011. Impact assessment of soil and water conservation measures at Medego watershed in Tigray, northern Ethiopia. Maejo International Journal of Science and Technology 5(3): 312-330.

Mengistu T., Demel T., Håkan H., Yonas Y. 2005. The Role of Communities in Closed Area Management in Ethiopia. Mountain Research and Development 25(1): 44-45. DOI: 10.1659/0276-4741(2005)025[0044:TR OCIC]2.0.CO;2

Minal T., Anil V. 2012. Mycorrhizae at polluted site of western rajasthan. International Journal of Plant, Animal and Environmental Sciences 2(4): 325-487.

Molla M., Kindeya G., Birhane E., Tewoldeberhan S. 2009. Regeneration, Density and Diversity of Woody Vegetation in Awash National Park, Ethiopia. Journal of the Drylands 2(2): 101-109.

Nedessa B., Ali J., Nyborg I. 2005. Exploring Ecological and Socio-Economic Issues for the Improvement of Area Enclosure Management a Case Study from Ethiopia. Drylands Coordination Group Report №38. Oslo: Mail Boxes ETC. 55 p.

Olsen S.R., Sommers L.E. 1982. Phosphorus. In: A.L. Page (Ed.): Methods of Soil Analysis, Part 2 Chemical and Microbiological Properties, №9. Madison, WI, USA: ASA Monograph. P. 403-430.
Reusing M., Schneider T., Ammer U. 2000. Modelling soil loss rates in the Ethiopian highlands by integration of high resolution MOMS-02/D2-stereo data in a GIS. Journal of Remote Sensing 21: 1885-1896.

Seyoum Y., Birhane E., Kassa H., Hagazi N., Esmael N., Mengistu T. 2015. Enhancing the role of the forestry sector in Ethiopia: strategy for scaling up effective forest management practices in Tigray Region with emphasis on area exclosures. Addis Ababa: CIFOR Ethiopia Office. 62 p.

Solomon D., Fritzche F., Lehmann J., Tekalign M., Zech W. 2002. Soil organic matter dynamics in the sub humid agro-ecosystems of the Ethiopian highlands: evidence from natural ${ }^{13} \mathrm{C}$ abundance and particlesize fraction. Soil Science Society of America Journal 66: 969-978.

Sonneveld B.G.J.S., Keyzer M.A. 2002. Land under pressure: soil conservation concerns and opportunities for Ethiopia. Land Degradation and Development 14(5): 5-23. DOI: 10.1002/ldr.503

Tadesse G. 2001. Land Degradation: A Challenge to Ethiopia. Journal of Environmental Management 27(6): 815824. DOI: $10.1007 / \mathrm{s} 002670010$

Tadesse G., Penden D. 2002. Livestock grazing impact on vegetation, soil and hydrology in a tropical highland watershed. Proceedings of MoWR/EARO/IWMI/ILRI International Workshop (ILRI, Addis Ababa, Ethiopia 2-4 December, 2002). Addis Ababa. P. 87-97.

Van Ranst E., Verloo M., Demeyer A., Pauwels J.M. 1999. Manual for the soil chemistry and fertility laboratory: analytical methods for soils and plants, equipments and management of consumables. Belgium: University of Gent. 243 p.

Wairore J.N.U., Mureithi S.M., Wasonga O.V., Nyberg G. 2015. Characterization of enclosure management regimes and factors influencing their choice among agropastoralists in North-Western Kenya. Pastoralism 5: 1-14. DOI: 10.1186/s13570-015-0036-7

World Bank. 2001. African Development Indicators. Washington D.C. 392 p.

WRB. 2006. World reference base for soil resources. $2^{\text {nd }}$ ed. World Soil Resources Reports №103. Rome: FAO. 128 p.

Yami M., Gebrehiwet K., Stein M., Mekuria W. 2006. Impact of Area Enclosures on Density and Diversity of Large Wild Mammals: The Case of May Ba'ati, Douga Tembien District, Central Tigray, Ethiopia. East African Journal of Sciences 1(1): 55-68.

Yayneshet T., Eik L.O., Moe S.R. 2009. The effects of exclosures in restoring degraded semi-arid vegetation in communal grazing lands in northern Ethiopia. Journal of Arid Environments 73: 542-549. DOI: 10.1016/j.jaridenv.2008.12.002

Yirdaw E. 2001. Diversity of naturally-regenerated native woody species in forest plantations in the Ethiopian highlands. New Forests 22: 159-177. DOI: 10.1023/A:1015629327039 
Appendix 1. AB, DE, FR, LF, trees and shrubs of all woody plants $(\mathrm{P}=0.000)$

\begin{tabular}{|c|c|c|c|c|c|c|c|c|c|c|c|}
\hline R.no & Plants of the Tigray highlands & Vernacular name & Family & LF & FR & $\%$ & $\mathrm{AB}$ & $\mathrm{DE}$ & \multicolumn{3}{|c|}{ Family frequency } \\
\hline 1 & Abutilon longicuspe Hochst. ex A. Rich. & Tsa'eda embwak & Malvaceae & $\mathrm{S}$ & 7 & 0.7 & 10 & 5.0 & Family & FR & $\%$ \\
\hline 2 & Acaia decurrens Willd. & Dikerens & Fabaceae & $\mathrm{T}$ & 13 & 1.3 & 59 & 29.5 & Acanthaceae & 1 & 0.1 \\
\hline 3 & Acacia etbaica Schweinf. & Seraw & Fabaceae & $\mathrm{T}$ & 53 & 5.3 & 439 & 219.5 & Aloeaceae & 16 & 1.6 \\
\hline 4 & Acacia lahai Benth. & Lahai & Fabaceae & $\mathrm{T}$ & 6 & 0.6 & 27 & 13.5 & Anacardiaceae & 30 & 3.0 \\
\hline 5 & Acacia saligna (Labill.) Wendl. & Acacha & Fabaceae & $\mathrm{T}$ & 24 & 2.4 & 195 & 97.5 & Apocynaceae & 37 & 3.7 \\
\hline 6 & Acokanthera schimpri (A. DC.) Schweinf. & Mebt'a & Apocynaceae & $\mathrm{T}$ & 11 & 1.1 & 99 & 49.5 & Asclepiadaceae & 1 & 0.1 \\
\hline 7 & Acacia seyal Delile & Tsa'eda che'a & Fabaceae & $\mathrm{T}$ & 65 & 6.6 & 223 & 111.5 & Asteraceae & 5 & 0.5 \\
\hline 8 & Aloe vera (A. barbadensis) (L.) Burm. f. & E'are & Aloeaceae & $\mathrm{S}$ & 16 & 1.6 & 163 & 81.5 & Berberidaceae & 2 & 0.2 \\
\hline 9 & Becium grandiflorum (Lam.) Pic. Serm. & Tebeb & Lamiaceae & $\mathrm{S}$ & 77 & 7.8 & 853 & 426.5 & Bignoniaceae & 5 & 0.5 \\
\hline 10 & Berberis holstii Engl. & Zinkila & Berberidaceae & $\mathrm{S}$ & 1 & 0.1 & 4 & 2.0 & Boraginaceae & 2 & 0.2 \\
\hline 11 & Buddleja polystachya Fresen. & Metere & Loganiaceae & $\mathrm{S}$ & 9 & 0.9 & 10 & 5.0 & Buddleiaceae & 6 & 0.6 \\
\hline 12 & Calpurinia aurea (Aiton) Benth. & Htsawts & Fabaceae & $\mathrm{S}$ & 41 & 4.1 & 177 & 88.5 & Cactaceae & 7 & 0.7 \\
\hline 13 & Cadaba farinosa Forssk. & Taum chena & Capparidaceae & $\mathrm{S}$ & 7 & 0.7 & 16 & 8.0 & Capparidaceae & 7 & 0.7 \\
\hline 14 & Carissa spinarum $\mathrm{L}$. & Agam & Apocynaceae & $\mathrm{S}$ & 26 & 2.6 & 35 & 17.5 & Celastraceae & 97 & 9.8 \\
\hline 15 & Clutia lanceolata Forssk. & Bokokot & Euphorbiaceae & $\mathrm{S}$ & 1 & 0.1 & 1 & 0.5 & Combretaceae & 17 & 1.7 \\
\hline 16 & Leucas oligocephala Hook. f. & Swakerni & Labiatae & $\mathrm{S}$ & 17 & 1.7 & 170 & 85.0 & Cupressaceae & 73 & 7.4 \\
\hline 17 & Cordia africana Lam. & Aqui & Boraginaceae & $\mathrm{T}$ & 2 & 0.2 & 2 & 1.0 & Ebenaceae & 96 & 9.7 \\
\hline 18 & Croton macrostachyus Hochst. ex Delile & Tanbuque & Euphorbiaceae & $\mathrm{T}$ & 17 & 1.7 & 33 & 16.5 & Ericaceae & 2 & 0.2 \\
\hline 19 & Cupressus lusitanica Mill. & Tsihidi ferenji & Cupressaceae & $\mathrm{T}$ & 8 & 0.8 & 30 & 15.0 & Euphorbiaceae & 31 & 3.1 \\
\hline 20 & Diospyros abyssinica (Hiern) F. White & Kumel a'awaf & Ebenaceae & $\mathrm{T}$ & 2 & 0.2 & 2 & 1.0 & Fabaceae & 227 & 22.9 \\
\hline 21 & Diplostigma canescens K. Schum. & Halengi & Asclepiadaceae & $\mathrm{S}$ & 1 & 0.1 & 2 & 1.0 & Flacourtiaceae & 10 & 1.0 \\
\hline 22 & Dichrostachys cinerea (L.) Wight \& Arn. & Gonnok & Fabaceae & $\mathrm{S}$ & 2 & 0.2 & 5 & 2.5 & Lamiaceae & 81 & 8.2 \\
\hline 23 & Dovyalis abyssinica (A. Rich.) Warb. & Aihada & Flacourtiaceae & $\mathrm{S}$ & 3 & 0.3 & 3 & 1.5 & Loganiaceae & 9 & 0.9 \\
\hline 24 & Dodonaea angustifolia L. f. & Tahsos & Sapindaceae & $\mathrm{S}$ & 55 & 5.5 & 1060 & 530.0 & Loranthaceae & 2 & 0.2 \\
\hline 25 & Ekebergia capensis Sparrm. & Kot & Meliaceae & $\mathrm{T}$ & 4 & 0.4 & 10 & 5.0 & Malvaceae & 7 & 0.7 \\
\hline 26 & Erica arborea $\mathrm{L}$. & Shanto & Ericaceae & $\mathrm{S}$ & 2 & 0.2 & 2 & 1.0 & Meliaceae & 4 & 0.4 \\
\hline 27 & Euphorbia abyssinica J.F. Gmel. & Kolkual & Euphorbiaceae & $\mathrm{T}$ & 13 & 1.3 & 41 & 20.5 & Moraceae & 3 & 0.3 \\
\hline 28 & Eucalyptus camaldulensis Dehnh. & Keyh bahr zaf & Myrtaceae & $\mathrm{T}$ & 37 & 3.7 & 191 & 95.5 & Myricaceae & 8 & 0.8 \\
\hline 29 & Eucalyptus globulus Labill. & Tsa'eda bahr zaf & Myrtaceae & $\mathrm{T}$ & 17 & 1.7 & 58 & 29.0 & Myrtaceae & 54 & 5.4 \\
\hline 30 & Euclea racemosa $\mathrm{L}$. & Kuli'aw & Ebenaceae & $\mathrm{S}$ & 94 & 9.5 & 847 & 423.5 & Oleaceae & 29 & 2.9 \\
\hline 31 & Ficus vasta Forssk. & Da'aro & Moraceae & $\mathrm{T}$ & 2 & 0.2 & 2 & 1.0 & Oliniaceae & 11 & 1.1 \\
\hline 32 & Grewia ferruginea Hochst. ex A. Rich. & Tsimkuya & Tiliaceae & $\mathrm{S}$ & 3 & 0.3 & 6 & 3.0 & Phytolaccaceae & 7 & 0.7 \\
\hline 33 & Grevillea robusta A.Cunn. ex R. Br. & Gravila & Proteaceae & $\mathrm{T}$ & 3 & 0.3 & 8 & 4.0 & Pittosporaceae & 1 & 0.1 \\
\hline 34 & Juniperus procera Hochst. ex Endl. & Tsihidi habesha & Cupressaceae & $\mathrm{T}$ & 65 & 6.6 & 256 & 128.0 & Polygonaceae & 11 & 1.1 \\
\hline 35 & $\begin{array}{l}\text { Justicia schimperiana (Hochst. ex Nees) T. } \\
\text { Anderson }\end{array}$ & Shim'aya & Acanthaceae & $\mathrm{S}$ & 1 & 0.1 & 1 & 0.5 & Proteaceae & 3 & 0.3 \\
\hline 36 & $\begin{array}{l}\text { Maytenus arbutifolia (Hochst. ex A. Rich.) } \\
\text { R. Wilczek }\end{array}$ & Atat & Celastraceae & $\mathrm{S}$ & 81 & 8.2 & 364 & 182.0 & Rhamnaceae & 9 & 0.9 \\
\hline 37 & Maytenus senegalensis (Lam.) Exell & Argudi/kebkeb & Celastraceae & $\mathrm{T}$ & 16 & 1.6 & 24 & 12.0 & Rosaceae & 8 & 0.8 \\
\hline 38 & Morus alba $\mathrm{L}$. & Yferenj injori & Moraceae & $\mathrm{T}$ & 1 & 0.1 & 1 & 0.5 & Rubiaceae & 2 & 0.2 \\
\hline 39 & Myrica salicifolia Hochst. ex A. Rich. & Nihibi & Myricaceae & $\mathrm{S}$ & 8 & 0.8 & 16 & 8.0 & Salicaceae & 5 & 0.5 \\
\hline 40 & Nuxia congesta $\mathrm{R}$. Br. ex Fresen. & Atkaro & Buddleiaceae & $\mathrm{T}$ & 6 & 0.6 & 8 & 4.0 & Sapindaceae & 55 & 5.5 \\
\hline 41 & Olea europaea L. & Awli'a & Oleaceae & $\mathrm{T}$ & 30 & 3.0 & 72 & 36.0 & Tiliaceae & 3 & 0.3 \\
\hline 42 & Olinia rochetiana A. Juss. & Shgmesrhi & Oliniaceae & $\mathrm{S}$ & 10 & 1.0 & 60 & 30.0 & Vitaceae & 7 & 0.7 \\
\hline 43 & Oncoba spinosa Forssk. & Eqot & Flacourtiaceae & $\mathrm{T}$ & 7 & 0.7 & 18 & 9.0 & Total & 991 & 100.0 \\
\hline 44 & Opuntia ficus indica (L.) Mill. & Beles & Cactaceae & $\mathrm{S}$ & 7 & 0.7 & 65 & 32.5 & & & \\
\hline 45 & Osyris quadripartita Salzm. ex Decne. & Kerets & Loranthaceae & $\mathrm{T}$ & 2 & 0.2 & 2 & 1.0 & & & \\
\hline 46 & Otostegia integrifolia Benth. & $\begin{array}{l}\text { Mesaguh/ } \\
\text { chi'andog }\end{array}$ & Lamiaceae & $\mathrm{S}$ & 6 & 0.6 & 23 & 11.5 & & & \\
\hline 47 & Phytolacca dodecandra L'Hér. & Shimiti & Phytolaccaceae & $\mathrm{S}$ & 7 & 0.7 & 13 & 6.5 & & & \\
\hline 48 & Pittosporum viridiflorum Sims & Chequente & Pittosporaceae & $\mathrm{T}$ & 1 & 0.1 & 3 & 1.5 & & & \\
\hline 49 & Prunus africana (Hook. f.) Kalkman & Tikur incheti & Rosaceae & $\mathrm{T}$ & 5 & 0.5 & 20 & 10.0 & & & \\
\hline 50 & Psydrax schimperiana (A. Rich.) Bridson & Zahak & Rubiaceae & $\mathrm{T}$ & 2 & 0.2 & 2 & 1.0 & & & \\
\hline 51 & Rhus glutinosa Hochst. ex A. Rich. & Mengi & Anacardiaceae & $\mathrm{T}$ & 15 & 1.5 & 38 & 19.0 & & & \\
\hline 52 & Rhamnus prinoids L'Hér. & Gesho & Rhamnaceae & $\mathrm{S}$ & 9 & 0.9 & 46 & 23.0 & & & \\
\hline 53 & Rhus retinorrhoea Steud. ex A. Rich. & Teta’alo & Anacardiaceae & $\mathrm{T}$ & 7 & 0.7 & 11 & 5.5 & & & \\
\hline 54 & $\begin{array}{l}\text { Rhoicissus tridentata (L. f.) Wild \& R.B. } \\
\text { Drumm. }\end{array}$ & Karshiro & Vitaceae & $\mathrm{S}$ & 7 & 0.7 & 18 & 9.0 & & & \\
\hline 55 & Rosa abyssinica $\mathrm{R} . \mathrm{Br}$. & Konteftefe & Rosaceae & $\mathrm{S}$ & 3 & 0.3 & 6 & 3.0 & & & \\
\hline 56 & Rumex nervosus Vahl & Hakot & Polygonaceae & $\mathrm{S}$ & 10 & 1.0 & 34 & 17.0 & & & \\
\hline 57 & Salix mucronata (S. subserrata) Thunb. & Kwaa & Salicaceae & $\mathrm{T}$ & 5 & 0.5 & 17 & 8.5 & & & \\
\hline 58 & Schinus molle L. & Qundo berbere & Anacardiaceae & $\mathrm{T}$ & 8 & 0.8 & 20 & 10.0 & & & \\
\hline 59 & Senna singueana (Delile) Lock & Hambhambo & Fabaceae & $\mathrm{S}$ & 23 & 2.3 & 65 & 32.5 & & & \\
\hline 60 & Stereospermum kunthianum Cham. & Argzana & Bignoniaceae & $\mathrm{T}$ & 5 & 0.5 & 13 & 6.5 & & & \\
\hline 61 & Vernonia amygdalina Delile & Grawa & Asteraceae & $\mathrm{S}$ & 5 & 0.5 & 15 & 7.5 & & & \\
\hline & Total & & & & 991 & 100 & 6014 & 3007 & & & \\
\hline
\end{tabular}

Hereafter: AB - Abundance, FR - Frequency, LF - Life form ( $\mathrm{S}$ - shrub, $\mathrm{T}$ - tree), DE - density. 
Appendix 2. AB, DE, FR, LF, trees and shrubs of woody plants in exclosures $(\mathrm{P}=0.000)$

\begin{tabular}{|c|c|c|c|c|c|c|c|c|c|c|c|}
\hline R.no & Plant species in exclosures & Vernacular name & Family & LF & FR & $\%$ & $\mathrm{AB}$ & $\mathrm{DE}$ & \multicolumn{3}{|c|}{ Family frequency } \\
\hline 1 & Abutilon longicuspe Hochst. ex A. Rich. & Tsa'eda embwak & Malvaceae & $\mathrm{S}$ & 6 & 0.9 & 9 & 8.4 & Family & FR & $\%$ \\
\hline 2 & Acaia decurrens Willd. & Dikerens & Fabaceae & $\mathrm{T}$ & 13 & 1.9 & 59 & 54.9 & Acanthaceae & 1 & 0.1 \\
\hline 3 & Acacia etbaica Schweinf. & Seraw & Fabaceae & $\mathrm{T}$ & 28 & 4.0 & 326 & 303.2 & Aloeaceae & 4 & 0.6 \\
\hline 4 & Acacia lahai Benth. & Lahai & Fabaceae & $\mathrm{T}$ & 6 & 0.9 & 27 & 25.1 & Anacardiaceae & 30 & 4.3 \\
\hline 5 & Acacia saligna (Labill.) Wendl. & Acacha & Fabaceae & $\mathrm{T}$ & 24 & 3.4 & 195 & 181.4 & Apocynaceae & 32 & 4.6 \\
\hline 6 & Acokanthera schimpri (A. DC.) Schweinf. & Mebti'a & Apocynaceae & $\mathrm{T}$ & 10 & 1.4 & 97 & 90.2 & Asclepiadaceae & 1 & 0.1 \\
\hline 7 & Acacia seyal Delile & Tsa'eda che'a & Fabaceae & $\mathrm{T}$ & 44 & 6.3 & 173 & 160.9 & Asteraceae & 5 & 0.7 \\
\hline 8 & Aloe vera (A. barbadensis) (L.) Burm. f. & E'are & Aloeaceae & $\mathrm{S}$ & 4 & 0.6 & 14 & 13.0 & Berberidaceae & 2 & 0.3 \\
\hline 9 & Becium grandiflorum (Lam.) Pic. Serm. & Tebeb & Lamiaceae & S & 53 & 7.6 & 708 & 658.4 & Bignoniaceae & 5 & 0.7 \\
\hline 10 & Berberis holstii Engl. & Zinkila & Berberidaceae & S & 1 & 0.1 & 4 & 3.7 & Boraginaceae & 2 & 0.3 \\
\hline 11 & Buddleja polystachya Fresen. & Metere & Loganiaceae & $\mathrm{S}$ & 5 & 0.7 & 6 & 5.6 & Buddleiaceae & 5 & 0.7 \\
\hline 12 & Calpurinia aurea (Aiton) Benth. & Htsawts & Fabaceae & $\mathrm{S}$ & 22 & 3.1 & 122 & 113.5 & Capparidaceae & 4 & 0.6 \\
\hline 13 & Cadaba farinosa Forssk. & T'aum chena & Capparidaceae & $\mathrm{S}$ & 4 & 0.6 & 11 & 10.2 & Celastraceae & 69 & 9.9 \\
\hline 14 & Carissa spinarum L. & Agam & Apocynaceae & $\mathrm{S}$ & 22 & 3.1 & 29 & 27.0 & Combretaceae & 12 & 1.7 \\
\hline 15 & Clutia lanceolata Forssk. & Bokokot & Euphorbiaceae & $\mathrm{S}$ & 1 & 0.1 & 1 & 0.9 & Cupressaceae & 50 & 7.2 \\
\hline 16 & Leucas oligocephala Hook. f. & Swakerni & Labiatae & $\mathrm{S}$ & 12 & 1.7 & 137 & 127.4 & Ebenaceae & 53 & 7.6 \\
\hline 17 & Cordia africana Lam. & Aqui & Boraginaceae & $\mathrm{T}$ & 2 & 0.3 & 2 & 1.9 & Ericaceae & 1 & 0.1 \\
\hline 18 & Croton macrostachyus Hochst. ex Delile & Tanbuque & Euphorbiaceae & $\mathrm{T}$ & 12 & 1.7 & 27 & 25.1 & Euphorbiaceae & 26 & 3.7 \\
\hline 19 & Cupressus lusitanica Mill. & Tsihidi ferengi & Cupressaceae & $\mathrm{T}$ & 7 & 1.0 & 29 & 27.0 & Fabaceae & 149 & 21.3 \\
\hline 20 & Diospyros abyssinica(Hiern) F. White & Kumel a'awaf & Ebenaceae & $\mathrm{T}$ & 2 & 0.3 & 2 & 1.9 & Flacourtiaceae & 10 & 1.4 \\
\hline 21 & Diplostigma canescens K. Schum. & Halengi & Asclepiadaceae & $\mathrm{S}$ & 1 & 0.1 & 2 & 1.9 & Lamiaceae & 58 & 8.3 \\
\hline 22 & Dichrostachys cinerea (L.) Wight \& Arn. & Gonnok & Fabaceae & S & 2 & 0.3 & 5 & 4.7 & Loganiaceae & 5 & 0.7 \\
\hline 23 & Dovyalis abyssinica (A. Rich.) Warb. & Aihada & Flacourtiaceae & $\mathrm{S}$ & 3 & 0.4 & 3 & 2.8 & Loranthaceae & 2 & 0.3 \\
\hline 24 & Dodonaea angustifolia L. f. & Tahsos & Sapindaceae & S & 49 & 7.0 & 1038 & 965.3 & Malvaceae & 6 & 0.9 \\
\hline 25 & Ekebergia capensis Sparrm. & Kot & Meliaceae & $\mathrm{T}$ & 4 & 0.6 & 10 & 9.3 & Meliaceae & 4 & 0.6 \\
\hline 26 & Erica arborea L. & Shanto & Ericaceae & S & 1 & 0.1 & 1 & 0.9 & Moraceae & 3 & 0.4 \\
\hline 27 & Euphorbia abyssinica J.F. Gmel. & Kolkual & Euphorbiaceae & $\mathrm{T}$ & 13 & 1.9 & 41 & 38.1 & Myricaceae & 8 & 1.1 \\
\hline 28 & Eucalyptus camaldulensis Dehnh. & Keyh bahr zaf & Myrtaceae & $\mathrm{T}$ & 17 & 2.4 & 76 & 70.7 & Myrtaceae & 22 & 3.1 \\
\hline 29 & Eucalyptus globulus Labill. & Tsa'eda bahr zaf & Myrtaceae & $\mathrm{T}$ & 5 & 0.7 & 24 & 22.3 & Oleaceae & 26 & 3.7 \\
\hline 30 & Euclea racemosa $\mathrm{L}$. & Kuli'aw & Ebenaceae & $\mathrm{S}$ & 51 & 7.3 & 466 & 433.4 & Oliniaceae & 8 & 1.1 \\
\hline 31 & Ficus vasta Forssk. & Da'aro & Moraceae & $\mathrm{T}$ & 2 & 0.3 & 2 & 1.9 & Phytolaccaceae & 7 & 1.0 \\
\hline 32 & Grewia ferruginea Hochst. ex A. Rich. & Tsimkuya & Tiliaceae & S & 3 & 0.4 & 6 & 5.6 & Pittosporaceae & 1 & 0.1 \\
\hline 33 & Grevillea robusta A. Cunn. ex R. Br. & Gravila & Proteaceae & $\mathrm{T}$ & 3 & 0.4 & 8 & 7.4 & Polygonaceae & 3 & 0.4 \\
\hline 34 & Juniperus procera Hochst. ex Endl. & Tsihidi habesha & Cupressaceae & $\mathrm{T}$ & 43 & 6.2 & 196 & 182.3 & Proteaceae & 3 & 0.4 \\
\hline 35 & $\begin{array}{l}\text { Justicia schimperiana (Hochst. ex Nees) T. } \\
\text { Anderson }\end{array}$ & Shim'aya & Acanthaceae & $\mathrm{S}$ & 1 & 0.1 & 1 & 0.9 & Rhamnaceae & 9 & 1.3 \\
\hline 36 & $\begin{array}{l}\text { Maytenus arbutifolia (Hochst. ex A. Rich.) } \\
\text { R. Wilczek }\end{array}$ & Atat & Celastraceae & $\mathrm{S}$ & 60 & 8.6 & 265 & 246.5 & Rosaceae & 8 & 1.1 \\
\hline 37 & Maytenus senegalensis (Lam.) Exell & Argudi & Celastraceae & $\mathrm{T}$ & 9 & 1.3 & 15 & 14.0 & Rubiaceae & 1 & 0.1 \\
\hline 38 & Morus alba L. & Yferenj injori & Moraceae & $\mathrm{T}$ & 1 & 0.1 & 1 & 0.9 & Salicaceae & 5 & 0.7 \\
\hline 39 & Myrica salicifolia Hochst. ex A. Rich. & Nihibi & Myricaceae & $\mathrm{S}$ & 8 & 1.1 & 16 & 14.9 & Sapindaceae & 49 & 7.0 \\
\hline 40 & Nuxia congesta $\mathrm{R}$. Br. ex Fresen. & Atkaro & Buddleiaceae & $\mathrm{T}$ & 5 & 0.7 & 6 & 5.6 & Tiliaceae & 3 & 0.4 \\
\hline 41 & Olea europaea L. & Awli'a & Oleaceae & $\mathrm{T}$ & 27 & 3.9 & 68 & 63.2 & Vitaceae & 7 & 1.0 \\
\hline 42 & Olinia rochetiana A. Juss. & Beye/Shimesrhi & Oliniaceae & $\mathrm{S}$ & 7 & 1.0 & 57 & 53.0 & Total & 699 & 100.0 \\
\hline 43 & Oncoba spinosa Forssk. & Eqot & Flacourtiaceae & $\mathrm{T}$ & 7 & 1.0 & 18 & 16.7 & & & \\
\hline 44 & Osyris quadripartita Salzm. ex Decne. & Kerets & Loranthaceae & $\mathrm{T}$ & 2 & 0.3 & 2 & 1.9 & & & \\
\hline 45 & Otostegia integrifolia Benth. & Chi'andog & Lamiaceae & $\mathrm{S}$ & 6 & 0.9 & 23 & 21.4 & & & \\
\hline 46 & Phytolacca dodecandra L'Hér. & Shimiti & Phytolaccaceae & $\mathrm{S}$ & 7 & 1.0 & 13 & 12.1 & & & \\
\hline 47 & Pittosporum viridiflorum Sims & Chequente & Pittosporaceae & $\mathrm{T}$ & 1 & 0.1 & 3 & 2.8 & & & \\
\hline 48 & Prunus africana (Hook. f.) Kalkman & Tikur incheti & Rosaceae & $\mathrm{T}$ & 5 & 0.7 & 20 & 18.6 & & & \\
\hline 49 & Psydrax schimperiana (A. Rich.) Bridson & Zahak & Rubiaceae & $\mathrm{T}$ & 1 & 0.1 & 1 & 0.9 & & & \\
\hline 50 & Rhus glutinosa Hochst. ex A. Rich. & Mengi & Anacardiaceae & $\mathrm{T}$ & 15 & 2.1 & 38 & 35.3 & & & \\
\hline 51 & Rhamnus prinoids L'Hér. & Gesho & Rhamnaceae & $\mathrm{S}$ & 9 & 1.3 & 46 & 42.8 & & & \\
\hline 52 & Rhus retinorrhoea Steud. ex A. Rich. & Teta'alo & Anacardiaceae & $\mathrm{T}$ & 7 & 1.0 & 11 & 10.2 & & & \\
\hline 53 & $\begin{array}{l}\text { Rhoicissus tridentata (L. f.) Wild \& R.B. } \\
\text { Drumm. }\end{array}$ & Karshiro & Vitaceae & $\mathrm{S}$ & 7 & 1.0 & 18 & 16.7 & & & \\
\hline 54 & Rosa abyssinica $\mathrm{R} . \mathrm{Br}$. & Konteftefe & Rosaceae & S & 3 & 0.4 & 6 & 5.6 & & & \\
\hline 55 & Rumex nervosus Vahl & Hakot & Polygonaceae & $\mathrm{S}$ & 3 & 0.4 & 8 & 7.4 & & & \\
\hline 56 & Salix mucronata (S. subserrata) Thunb. & Kwaa & Salicaceae & $\mathrm{T}$ & 5 & 0.7 & 17 & 15.8 & & & \\
\hline 57 & Schinus molle L. & Qundo berbere & Anacardiaceae & $\mathrm{T}$ & 8 & 1.1 & 20 & 18.6 & & & \\
\hline 58 & Senna singueana (Delile) Lock & Hambhambo & Fabaceae & $\mathrm{S}$ & 10 & 1.4 & 32 & 29.8 & & & \\
\hline 59 & Stereospermum kunthianum Cham. & Argzana & Bignoniaceae & $\mathrm{T}$ & 5 & 0.7 & 13 & 12.1 & & & \\
\hline 60 & Vernonia amygdalina Delile & Grawa & Asteraceae & $\mathrm{T}$ & 5 & 0.7 & 15 & 14.0 & & & \\
\hline & Total & & & & 699 & 100 & 4589 & 4267.8 & & & \\
\hline
\end{tabular}


Appendix 3. AB, DE, FR, LF, trees and shrubs of woody plants in grazing land $(\mathrm{P}=0.000)$

\begin{tabular}{|c|c|c|c|c|c|c|c|c|c|c|c|}
\hline R.no & Plant species of grazing lands & $\begin{array}{c}\text { Vernacular } \\
\text { name }\end{array}$ & Family & $\mathrm{LF}$ & FR & $\%$ & $\mathrm{AB}$ & $\mathrm{DE}$ & Family fi & quenc & \\
\hline 1 & $\begin{array}{l}\text { Abutilon longicuspe Hochst. ex } \\
\text { A. Rich. }\end{array}$ & $\begin{array}{l}\text { Tsa'eda } \\
\text { embwak }\end{array}$ & Malvaceae & $\mathrm{S}$ & 1 & 0.3 & 1 & 0.9 & Families & FR & $\%$ \\
\hline 2 & Acacia etbaica Schweinf. & Seraw & Fabaceae & $\mathrm{T}$ & 25 & 8.6 & 113 & 105.1 & Aloeaceae & 12 & 4.1 \\
\hline 3 & $\begin{array}{l}\text { Acokanthera schimpri (A. DC.) } \\
\text { Schweinf. }\end{array}$ & Mebt'a & Apocynaceae & $\mathrm{T}$ & 1 & 0.3 & 2 & 1.9 & Apocynaceae & 5 & 1.7 \\
\hline 4 & Acacia seyal Delile & Tsa'eda che'a & Fabaceae & $\mathrm{T}$ & 21 & 7.2 & 50 & 46.5 & Buddleiaceae & 1 & 0.3 \\
\hline 5 & Aloe vera (L.) Burm. f. & E'are & Aloeaceae & $\mathrm{S}$ & 12 & 4.1 & 149 & 138.6 & Cactaceae & 7 & 2.4 \\
\hline 6 & $\begin{array}{l}\text { Becium grandiflorum (Lam.) } \\
\text { Pic. Serm. }\end{array}$ & Tebeb & Lamiaceae & $\mathrm{S}$ & 24 & 8.2 & 145 & 134.9 & Capparidaceae & 3 & 1.0 \\
\hline 7 & Buddleja polystachya Fresen. & Metere & Loganiaceae & $\mathrm{S}$ & 4 & 1.4 & 4 & 3.7 & Celastraceae & 28 & 9.6 \\
\hline 8 & $\begin{array}{l}\text { Calpurinia aurea (Aiton) } \\
\text { Benth. }\end{array}$ & Htsawts & Fabaceae & $\mathrm{S}$ & 19 & 6.5 & 55 & 51.2 & Combretaceae & 5 & 1.7 \\
\hline 9 & Cadaba farinose Forssk. & Taum chena & Capparidaceae & $\mathrm{S}$ & 3 & 1.0 & 5 & 4.7 & Cupressaceae & 23 & 7.9 \\
\hline 10 & Carissa spinarum $\mathrm{L}$. & Agam & Apocynaceae & $\mathrm{S}$ & 4 & 1.4 & 6 & 5.6 & Ebenaceae & 43 & 14.7 \\
\hline 11 & Leucas oligocephala Hook. f. & Swakerni & Labiatae & $\mathrm{S}$ & 5 & 1.7 & 33 & 30.7 & Ericaceae & 1 & 0.3 \\
\hline 12 & $\begin{array}{l}\text { Croton macrostachyus Hochst. } \\
\text { ex Delile }\end{array}$ & Tanbuque & Euphorbiaceae & $\mathrm{T}$ & 5 & 1.7 & 6 & 5.6 & Euphorbiaceae & 5 & 1.7 \\
\hline 13 & Cupressus lusitanica Mill. & Tsihidi ferenji & Cupressaceae & $\mathrm{T}$ & 1 & 0.3 & 1 & 0.9 & Fabaceae & 78 & 26.7 \\
\hline 14 & Dodonaea angustifolia L. f. & Tahsos & Sapindaceae & $\mathrm{S}$ & 6 & 2.1 & 22 & 20.5 & Lamiaceae & 23 & 7.9 \\
\hline 15 & Erica arborea L. & Shanto & Ericaceae & $\mathrm{S}$ & 1 & 0.3 & 1 & 0.9 & Loganiaceae & 4 & 1.4 \\
\hline 16 & $\begin{array}{l}\text { Eucalyptus camaldulensis } \\
\text { Dehnh. }\end{array}$ & Keyh bahr zaf & Myrtaceae & $\mathrm{T}$ & 20 & 6.8 & 115 & 107.0 & Malvaceae & 1 & 0.3 \\
\hline 17 & Eucalyptus globulus Labill. & Tsa'eda bahr zaf & Myrtaceae & $\mathrm{T}$ & 12 & 4.1 & 34 & 31.6 & Myrtaceae & 32 & 11.0 \\
\hline 18 & Euclea racemose L. & Kuli'aw & Ebenaceae & $\mathrm{S}$ & 43 & 14.7 & 381 & 354.3 & Oleaceae & 3 & 1.0 \\
\hline 19 & $\begin{array}{l}\text { Juniperus procera Hochst. ex } \\
\text { Endl. }\end{array}$ & Tsihidi habesha & Cupressaceae & $\mathrm{T}$ & 22 & 7.5 & 60 & 55.8 & Oliniaceae & 3 & 1.0 \\
\hline 20 & $\begin{array}{l}\text { Maytenus arbutifolia (Hochst. } \\
\text { ex A. Rich.) R. Wilczek }\end{array}$ & Atat & Celastraceae & $\mathrm{S}$ & 21 & 7.2 & 99 & 92.1 & Polygonaceae & 8 & 2.7 \\
\hline 21 & $\begin{array}{l}\text { Maytenus senegalensis (Lam.) } \\
\text { Exell }\end{array}$ & Argudi/kebkeb & Celastraceae & $\mathrm{T}$ & 7 & 2.4 & 9 & 8.4 & Rubiaceae & 1 & 0.3 \\
\hline 22 & $\begin{array}{l}\text { Nuxia congesta } \mathrm{R} \text {. Br. ex } \\
\text { Fresen. }\end{array}$ & Atkaro & Buddleiaceae & $\mathrm{T}$ & 1 & 0.3 & 2 & 1.9 & Sapindaceae & 6 & 2.1 \\
\hline 23 & Olea europaea L. & Awli'a & Oleaceae & $\mathrm{T}$ & 3 & 1.0 & 4 & 3.7 & Total & 292 & 100.0 \\
\hline 24 & Olinia rochetiana A. Juss. & Shgmesrhi & Oliniaceae & $\mathrm{S}$ & 3 & 1.0 & 3 & 2.8 & & & \\
\hline 25 & Opuntia ficus indica (L.) Mill. & Beles & Cactaceae & $\mathrm{S}$ & 7 & 2.4 & 65 & 60.5 & & & \\
\hline 26 & $\begin{array}{l}\text { Psydrax schimperiana } \\
\text { (A.Rich.) Bridson }\end{array}$ & Zahak & Rubiaceae & $\mathrm{T}$ & 1 & 0.3 & 1 & 0.9 & & & \\
\hline 27 & Rumex nervosus Vahl & Hakot & Polygonaceae & $\mathrm{S}$ & 7 & 2.4 & 26 & 24.2 & & & \\
\hline \multirow[t]{2}{*}{28} & Senna singueana (Delile) Lock & Hambhambo & Fabaceae & $\mathrm{S}$ & 13 & 4.5 & 33 & 30.7 & & & \\
\hline & Total & & & & 292 & 100 & 1425 & 1325.3 & & & \\
\hline
\end{tabular}


Appendix 4. AB, DE, FR, LF, trees and shrubs of woody plants in foot elevation $(\mathrm{P}=0.000)$

\begin{tabular}{|c|c|c|c|c|c|c|c|c|c|c|c|}
\hline R.no & Plant of foot slope & Vernacular name & Family & LF & FR & $\%$ & $\mathrm{AB}$ & $\mathrm{DE}$ & \multicolumn{3}{|c|}{ Family frequency } \\
\hline 1 & Abutilon longicuspe Hochst. ex A. Rich. & Tsa'eda embwak & Malvaceae & $\mathrm{S}$ & 2 & 0.5 & 2 & 2.8 & Family & FR & $\%$ \\
\hline 2 & Acaia decurrens Willd. & Dikerens & Fabaceae & $\mathrm{T}$ & 7 & 1.7 & 31 & 43.4 & Acanthaceae & 1 & 0.2 \\
\hline 3 & Acacia etbaica Schweinf. & Seraw & Fabaceae & $\mathrm{T}$ & 18 & 4.4 & 126 & 176.4 & Aloeaceae & 2 & 0.5 \\
\hline 4 & Acacia lahai Benth. & Lahai & Fabaceae & $\mathrm{T}$ & 3 & 0.7 & 11 & 15.4 & Anacardiaceae & 13 & 3.2 \\
\hline 5 & Acacia saligna (Labill.) Wendl. & Acacha & Fabaceae & $\mathrm{T}$ & 10 & 2.5 & 72 & 100.8 & Apocynaceae & 14 & 3.4 \\
\hline 6 & Acokanthera schimpri (A. DC.) Schweinf. & Mebti'a & Apocynaceae & $\mathrm{T}$ & 3 & 0.7 & 27 & 37.8 & Asteraceae & 3 & 0.7 \\
\hline 7 & Acacia seyal Delile & Tsa'eda che'a & Fabaceae & $\mathrm{T}$ & 29 & 7.1 & 101 & 141.4 & Berberidaceae & 1 & 0.2 \\
\hline 8 & Aloe vera (A. barbadensis) (L.) Burm. f. & E'are & Aloeaceae & $\mathrm{S}$ & 2 & 0.5 & 3 & 4.2 & Bignoniaceae & 3 & 0.7 \\
\hline 9 & Becium grandiflorum (Lam.) Pic. Serm. & Tebeb & Lamiaceae & $\mathrm{S}$ & 25 & 6.1 & 393 & 550.2 & Boraginaceae & 2 & 0.5 \\
\hline 10 & Berberis holstii Engl. & Zinkila & Berberidaceae & S & 1 & 0.2 & 2 & 2.8 & Buddleiaceae & 3 & 0.7 \\
\hline 11 & Buddleja polystachya Fresen. & Metere & Loganiaceae & $\mathrm{S}$ & 3 & 0.7 & 4 & 5.6 & Cactaceae & 3 & 0.7 \\
\hline 12 & Calpurinia aurea (Aiton) Benth. & Htsawts & Fabaceae & S & 14 & 3.4 & 41 & 57.4 & Capparidaceae & 1 & 0.2 \\
\hline 13 & Cadaba farinosa Forssk. & T'aum chena & Capparidaceae & S & 1 & 0.2 & 1 & 1.4 & Celastraceae & 35 & 8.6 \\
\hline 14 & Carissa spinarum L. & Agam & Apocynaceae & S & 12 & 2.9 & 14 & 19.6 & Combretaceae & 7 & 1.7 \\
\hline 15 & Clutia lanceolata Forssk. & Bokokot & Euphorbiaceae & $\mathrm{S}$ & 1 & 0.2 & 1 & 1.4 & Cupressaceae & 26 & 6.4 \\
\hline 16 & Leucas oligocephala Hook. f. & Swakerni & Labiatae & $\mathrm{S}$ & 7 & 1.7 & 82 & 114.8 & Ebenaceae & 30 & 7.4 \\
\hline 17 & Cordia africana Lam. & Aqui & Boraginaceae & $\mathrm{T}$ & 2 & 0.5 & 2 & 2.8 & Ericaceae & 1 & 0.2 \\
\hline 18 & Croton macrostachyus Hochst. ex Delile & Tanbuque & Euphorbiaceae & $\mathrm{T}$ & 11 & 2.7 & 26 & 36.4 & Euphorbiaceae & 19 & 4.7 \\
\hline 19 & Cupressus lusitanica Mill. & Tsihidi ferenji & Cupressaceae & $\mathrm{T}$ & 2 & 0.5 & 5 & 7 & Fabaceae & 96 & 23.5 \\
\hline 20 & Dovyalis abyssinica (A. Rich.) Warb. & Aihada & Flacourtiaceae & S & 1 & 0.2 & 1 & 1.4 & Flacourtiaceae & 6 & 1.5 \\
\hline 21 & Dodonaea angustifolia L. f. & Tahsos & Sapindaceae & $\mathrm{S}$ & 22 & 5.4 & 254 & 355.6 & Lamiaceae & 29 & 7.1 \\
\hline 22 & Ekebergia capensis Sparrm. & Kot & Meliaceae & $\mathrm{T}$ & 3 & 0.7 & 4 & 5.6 & Loganiaceae & 3 & 0.7 \\
\hline 23 & Erica arborea L. & Shanto & Ericaceae & $\mathrm{S}$ & 1 & 0.2 & 1 & 1.4 & Malvaceae & 2 & 0.5 \\
\hline 24 & Euphorbia abyssinica J.F. Gmel. & Kolkual & Euphorbiaceae & $\mathrm{T}$ & 7 & 1.7 & 23 & 32.2 & Meliaceae & 3 & 0.7 \\
\hline 25 & Eucalyptus camaldulensis Dehnh. & Keyh bahr zaf & Myrtaceae & $\mathrm{T}$ & 13 & 3.2 & 74 & 103.6 & Moraceae & 2 & 0.5 \\
\hline 26 & Eucalyptus globulus Labill. & Tsa'eda bahir zaf & Myrtaceae & $\mathrm{T}$ & 7 & 1.7 & 22 & 30.8 & Myricaceae & 6 & 1.5 \\
\hline 27 & Euclea racemosa L. & Kuli'aw & Ebenaceae & S & 30 & 7.4 & 304 & 425.6 & Myrtaceae & 20 & 4.9 \\
\hline 28 & Ficus vasta Forssk. & Da'aro & Moraceae & $\mathrm{T}$ & 1 & 0.2 & 1 & 1.4 & Oleaceae & 11 & 2.7 \\
\hline 29 & Grewia ferruginea Hochst. ex A. Rich. & Tsimkuya & Tiliaceae & S & 1 & 0.2 & 2 & 2.8 & Oliniaceae & 6 & 1.5 \\
\hline 30 & Grevillea robusta A. Cunn. ex R. Br. & Gravila & Proteaceae & $\mathrm{T}$ & 2 & 0.5 & 7 & 9.8 & Phytolaccaceae & 6 & 1.5 \\
\hline 31 & Juniperus procera Hochst. ex Endl. & Tsihidi habesha & Cupressaceae & $\mathrm{T}$ & 24 & 5.9 & 93 & 130.2 & Pittosporaceae & 1 & 0.2 \\
\hline 32 & $\begin{array}{l}\text { Justicia schimperiana (Hochst. ex Nees) } \\
\text { T. Anderson }\end{array}$ & Shim'aya & Acanthaceae & S & 1 & 0.2 & 1 & 1.4 & Polygonaceae & 8 & 2.0 \\
\hline 33 & $\begin{array}{l}\text { Maytenus arbutifolia (Hochst. ex A. } \\
\text { Rich.) R. Wilczek }\end{array}$ & Atat & Celastraceae & $\mathrm{S}$ & 29 & 7.1 & 157 & 219.8 & Proteaceae & 2 & 0.5 \\
\hline 34 & Maytenus senegalensis (Lam.) Exell & Argudi & Celastraceae & $\mathrm{T}$ & 6 & 1.5 & 9 & 12.6 & Rhamnaceae & 6 & 1.5 \\
\hline 35 & Morus alba $\mathrm{L}$. & Yferenj injori & Moraceae & $\mathrm{T}$ & 1 & 0.2 & 1 & 1.4 & Rosaceae & 3 & 0.7 \\
\hline 36 & Myrica salicifolia Hochst. ex A. Rich. & Nihibi & Myricaceae & S & 6 & 1.5 & 14 & 19.6 & Rubiaceae & 2 & 0.5 \\
\hline 37 & Nuxia congesta $\mathrm{R}$. Br. ex Fresen. & Atkaro & Buddleiaceae & $\mathrm{T}$ & 3 & 0.7 & 4 & 5.6 & Salicaceae & 3 & 0.7 \\
\hline 38 & Olea europaea L. & Awli'a & Oleaceae & $\mathrm{T}$ & 11 & 2.7 & 25 & 35 & Sapindaceae & 22 & 5.4 \\
\hline 39 & Olinia rochetiana A. Juss. & Beye/Shimesrhi & Oliniaceae & $\mathrm{S}$ & 6 & 1.5 & 44 & 61.6 & Tiliaceae & 1 & 0.2 \\
\hline 40 & Oncoba spinosa Forssk. & Eqot & Flacourtiaceae & $\mathrm{T}$ & 5 & 1.2 & 16 & 22.4 & Vitaceae & 6 & 1.5 \\
\hline 41 & Opuntia ficus indica (L.) Mill. & Beles & Cactaceae & S & 3 & 0.7 & 23 & 32.2 & Total & 408 & 100 \\
\hline 42 & Otostegia integrifolia Benth. & $\begin{array}{l}\text { Mesaguh/ } \\
\text { chi'andog }\end{array}$ & Lamiaceae & $\mathrm{S}$ & 5 & 1.2 & 12 & 16.8 & & & \\
\hline 43 & Phytolacca dodecandra L'Hér. & Shimiti & Phytolaccaceae & S & 6 & 1.5 & 12 & 16.8 & & & \\
\hline 44 & Pittosporum viridiflorum Sims & Chequente & Pittosporaceae & $\mathrm{T}$ & 1 & 0.2 & 3 & 4.2 & & & \\
\hline 45 & Prunus africana (Hook. f.) Kalkman & Tikur incheti & Rosaceae & $\mathrm{T}$ & 3 & 0.7 & 16 & 22.4 & & & \\
\hline 46 & Psydrax schimperiana (A. Rich.) Bridson & Zahak & Rubiaceae & S & 2 & 0.5 & 2 & 2.8 & & & \\
\hline 47 & Rhus glutinosa Hochst. ex A. Rich. & Mengi/hatami & Anacardiaceae & $\mathrm{T}$ & 5 & 1.2 & 7 & 9.8 & & & \\
\hline 48 & Rhamnus prinoids L'Hér. & Gesho & Rhamnaceae & S & 6 & 1.5 & 37 & 51.8 & & & \\
\hline 49 & Rhus retinorrhoea Steud. ex A. Rich. & Teta'alo & Anacardiaceae & $\mathrm{T}$ & 2 & 0.5 & 4 & 5.6 & & & \\
\hline 50 & $\begin{array}{l}\text { Rhoicissus tridentata (L. f.) Wild \& R.B. } \\
\text { Drumm. }\end{array}$ & Karshiro & Vitaceae & S & 6 & 1.5 & 17 & 23.8 & & & \\
\hline 51 & Rumex nervosus Vahl & Hakot & Polygonaceae & $\mathrm{S}$ & 7 & 1.7 & 27 & 37.8 & & & \\
\hline 52 & Salix mucronata (S. subserrata) Thunb. & Kwaa & Salicaceae & $\mathrm{T}$ & 3 & 0.7 & 13 & 18.2 & & & \\
\hline 53 & Schinus molle L. & Qundo berbere & Anacardiaceae & $\mathrm{T}$ & 6 & 1.5 & 16 & 22.4 & & & \\
\hline 54 & Senna singueana (Delile) Lock & Hambhambo & Fabaceae & S & 14 & 3.4 & 43 & 60.2 & & & \\
\hline 55 & Stereospermum kunthianum Cham. & Argzana & Bignoniaceae & $\mathrm{T}$ & 3 & 0.7 & 11 & 15.4 & & & \\
\hline 56 & Vernonia amygdalina Delile & Grawa & Asteraceae & $\mathrm{T}$ & 3 & 0.7 & 11 & 15.4 & & & \\
\hline & Total & & & & 408 & 100 & 2255 & 3157 & & & \\
\hline
\end{tabular}


Appendix 5. AB, DE, FR, LF, trees and shrubs of woody plants in middle elevation $(\mathrm{P}=0.000)$

\begin{tabular}{|c|c|c|c|c|c|c|c|c|c|c|c|}
\hline R.no & Plants of middle slope & $\begin{array}{l}\text { Vernacular } \\
\text { name }\end{array}$ & Family & LF & FR & $\%$ & $\mathrm{AB}$ & $\mathrm{DE}$ & \multicolumn{3}{|c|}{ Family frequency } \\
\hline 1 & $\begin{array}{l}\text { Abutilon longicuspe Hochst. ex } \\
\text { A. Rich. }\end{array}$ & Tsa'eda embwak & Malvaceae & $\mathrm{S}$ & 4 & 1.3 & 6 & 8.4 & Family & FR & $\%$ \\
\hline 3 & Acacia etbaica Schweinf. & Seraw & Fabaceae & $\mathrm{T}$ & 19 & 6.0 & 205 & 287 & Anacardiaceae & 9 & 2.8 \\
\hline 4 & Acacia lahai Benth. & Lahai & Fabaceae & $\mathrm{T}$ & 1 & 0.3 & 8 & 11.2 & Apocynaceae & 10 & 3.2 \\
\hline 5 & Acacia saligna (Labill.) Wendl. & Acacha & Fabaceae & $\mathrm{T}$ & 8 & 2.5 & 64 & 89.6 & Asteraceae & 2 & 0.6 \\
\hline 7 & Acacia seyal Delile & Tsa'eda che'a & Fabaceae & $\mathrm{S}$ & 21 & 6.6 & 70 & 98 & Buddleiaceae & 2 & 0.6 \\
\hline 8 & $\begin{array}{l}\text { Aloe vera (A. barbadensis) (L.) } \\
\text { Burm. f. }\end{array}$ & E'are & Aloeaceae & $\mathrm{S}$ & 8 & 2.5 & 59 & 82.6 & Cactaceae & 3 & 0.9 \\
\hline 9 & $\begin{array}{l}\text { Becium grandiflorum (Lam.) Pic. } \\
\text { Serm. }\end{array}$ & Tebeb & Lamiaceae & $\mathrm{S}$ & 28 & 8.8 & 236 & 330.4 & Capparidaceae & 4 & 1.3 \\
\hline 10 & Buddleja polystachya Fresen. & Metere & Loganiaceae & S & 3 & 0.9 & 3 & 4.2 & Celastraceae & 28 & 8.8 \\
\hline 11 & Calpurinia aurea (Aiton) Benth. & Htsawts & Fabaceae & S & 16 & 5.0 & 86 & 120.4 & Combretaceae & 7 & 2.2 \\
\hline 13 & Carissa spinarum L. & Agam & Apocynaceae & $\mathrm{S}$ & 6 & 1.9 & 7 & 9.8 & Ebenaceae & 33 & 10.4 \\
\hline 14 & Leucas oligocephala Hook.f. & Swakerni & Labiatae & $\mathrm{S}$ & 7 & 2.2 & 48 & 67.2 & Euphorbiaceae & 7 & 2.2 \\
\hline 15 & $\begin{array}{l}\text { Croton macrostachyus Hochst. ex } \\
\text { Delile }\end{array}$ & Tanbuque & Euphorbiaceae & $\mathrm{T}$ & 4 & 1.3 & 5 & 7 & Fabaceae & 76 & 24.0 \\
\hline 16 & Cupressus lusitanica Mill. & Tsihidi ferengi & Cupressaceae & $\mathrm{T}$ & 2 & 0.6 & 4 & 5.6 & Flacourtiaceae & 3 & 0.9 \\
\hline 17 & $\begin{array}{l}\text { Dichrostachys cinerea (L.) Wight } \\
\text { \& Arn. }\end{array}$ & Gonnok & Fabaceae & $\mathrm{S}$ & 1 & 0.3 & 3 & 4.2 & Lamiaceae & 29 & 9.1 \\
\hline 18 & $\begin{array}{l}\text { Dovyalis abyssinica (A. Rich.) } \\
\text { Warb. }\end{array}$ & Aihada & Flacourtiaceae & $\mathrm{S}$ & 1 & 0.3 & 1 & 1.4 & Loganiaceae & 3 & 0.9 \\
\hline 19 & Dodonaea angustifolia L. f. & Tahsos & Sapindaceae & $\mathrm{S}$ & 19 & 6.0 & 413 & 578.2 & Loranthaceae & 1 & 0.3 \\
\hline 20 & Ekebergia capensis Sparrm. & Kot & Meliaceae & $\mathrm{T}$ & 1 & 0.3 & 6 & 8.4 & Malvaceae & 4 & 1.3 \\
\hline 21 & Euphorbia abyssinica J.F. Gmel. & kolqual & Euphorbiaceae & $\mathrm{T}$ & 3 & 0.9 & 12 & 16.8 & Meliaceae & 1 & 0.3 \\
\hline 22 & Eucalyptus camaldulensis Dehnh. & Keyh bahr zaf & Myrtaceae & $\mathrm{T}$ & 14 & 4.4 & 72 & 100.8 & Moraceae & 1 & 0.3 \\
\hline 23 & Eucalyptus globulus Labill. & Tsa'eda bahr zaf & Myrtaceae & $\mathrm{T}$ & 5 & 1.6 & 23 & 32.2 & Myricaceae & 2 & 0.6 \\
\hline 24 & Euclea racemosa L. & Kuli'aw & Ebenaceae & $\mathrm{S}$ & 33 & 10.4 & 265 & 371 & Myrtaceae & 19 & 6.0 \\
\hline 26 & Juniperus procera Hochst. ex Endl. & Tsihidi habesha & Cupressaceae & $\mathrm{T}$ & 19 & 6.0 & 67 & 93.8 & Oliniaceae & 2 & 0.6 \\
\hline 27 & $\begin{array}{l}\text { Maytenus arbutifolia (Hochst. ex } \\
\text { A. Rich.) R. Wilczek }\end{array}$ & Atat & Celastraceae & $\mathrm{S}$ & 23 & 7.3 & 87 & 121.8 & Phytolaccaceae & 1 & 0.3 \\
\hline 28 & $\begin{array}{l}\text { Maytenus senegalensis (Lam.) } \\
\text { Exell }\end{array}$ & Argudi/kebkeb & Celastraceae & $\mathrm{T}$ & 5 & 1.6 & 6 & 8.4 & Polygonaceae & 1 & 0.3 \\
\hline 29 & $\begin{array}{l}\text { Myrica salicifolia Hochst. ex A. } \\
\text { Rich. }\end{array}$ & Nihibi & Myricaceae & S & 2 & 0.6 & 2 & 2.8 & Rhamnaceae & 3 & 0.9 \\
\hline 30 & Nuxia congesta $\mathrm{R}$. Br. ex Fresen. & Atkaro & Buddleiaceae & $\mathrm{T}$ & 2 & 0.6 & 3 & 4.2 & Rosaceae & 4 & 1.3 \\
\hline 31 & Olea europaea $\mathrm{L}$. & Awli'a & Oleaceae & $\mathrm{T}$ & 9 & 2.8 & 21 & 29.4 & Salicaceae & 2 & 0.6 \\
\hline 32 & Olinia rochetiana A. Juss. & Shgmesrhi & Oliniaceae & $\mathrm{S}$ & 2 & 0.6 & 2 & 2.8 & Sapindaceae & 19 & 6.0 \\
\hline 33 & Oncoba spinosa Forssk. & Eqot & Flacourtiaceae & $\mathrm{T}$ & 2 & 0.6 & 2 & 2.8 & Vitaceae & 1 & 0.3 \\
\hline 34 & Opuntia ficus indica (L.) Mill. & Beles & Cactaceae & $\mathrm{S}$ & 3 & 0.9 & 37 & 51.8 & Total & 317 & 100.0 \\
\hline 35 & $\begin{array}{l}\text { Osyris quadripartita Salzm. ex } \\
\text { Decne. }\end{array}$ & Kerets & Loranthaceae & $\mathrm{T}$ & 1 & 0.3 & 1 & 1.4 & & & \\
\hline 36 & Otostegia integrifolia Benth. & Chi'andog & Lamiaceae & $\mathrm{S}$ & 1 & 0.3 & 11 & 15.4 & & & \\
\hline 37 & Phytolacca dodecandra L'Hér. & Shimiti & Phytolaccaceae & $\mathrm{S}$ & 1 & 0.3 & 1 & 1.4 & & & \\
\hline 38 & $\begin{array}{l}\text { Prunus africana (Hook. f.) } \\
\text { Kalkman }\end{array}$ & Tikur incheti & Rosaceae & $\mathrm{T}$ & 2 & 0.6 & 4 & 5.6 & & & \\
\hline 39 & Rhus glutinosa Hochst. ex A. Rich. & Mengi & Anacardiaceae & $\mathrm{T}$ & 5 & 1.6 & 7 & 9.8 & & & \\
\hline 40 & Rhamnus prinoids L'Hér. & Gesho & Rhamnaceae & $\mathrm{S}$ & 3 & 0.9 & 9 & 12.6 & & & \\
\hline 41 & $\begin{array}{l}\text { Rhus retinorrhoea Steud. ex A. } \\
\text { Rich. }\end{array}$ & Teta'alo & Anacardiaceae & $\mathrm{T}$ & 2 & 0.6 & 2 & 2.8 & & & \\
\hline 42 & $\begin{array}{l}\text { Rhoicissus tridentata (L. f.) Wild } \\
\text { \& R.B. Drumm. }\end{array}$ & Karshiro & Vitaceae & $\mathrm{S}$ & 1 & 0.3 & 1 & 1.4 & & & \\
\hline 43 & Rosa abyssinica $\mathrm{R} . \mathrm{Br}$. & Konteftefe & Rosaceae & $\mathrm{S}$ & 2 & 0.6 & 5 & 7 & & & \\
\hline 44 & Rumex nervosus Vahl & Hakot & Polygonaceae & $\mathrm{S}$ & 1 & 0.3 & 1 & 1.4 & & & \\
\hline 45 & $\begin{array}{l}\text { Salix mucronata (S. subserrata) } \\
\text { Thunb. }\end{array}$ & Kwaa & Salicaceae & $\mathrm{T}$ & 2 & 0.6 & 4 & 5.6 & & & \\
\hline 46 & Schinus molle L. & Qundo berbere & Anacardiaceae & $\mathrm{T}$ & 2 & 0.6 & 4 & 5.6 & & & \\
\hline 47 & Senna singueana (Delile) Lock & Hambhambo & Fabaceae & $\mathrm{S}$ & 7 & 2.2 & 19 & 26.6 & & & \\
\hline 48 & Stereospermum kunthianum Cham. & Argzana & Bignoniaceae & $\mathrm{T}$ & 2 & 0.6 & 2 & 2.8 & & & \\
\hline
\end{tabular}


Appendix 6. AB, DE, FR, LF, trees and shrubs of woody plants in upper elevation $(\mathrm{P}=0.002)$

\begin{tabular}{|c|c|c|c|c|c|c|c|c|c|c|c|}
\hline R.no & Plant in upper slope & Vernacular name & Family & $\mathrm{LF}$ & FR & $\%$ & $\mathrm{AB}$ & $\mathrm{DE}$ & \multicolumn{3}{|c|}{ Family frequency } \\
\hline 1 & Abutilon longicuspe Hochst. ex A. Rich. & Tsa'eda embwak & Malvaceae & $\mathrm{S}$ & 1 & 0.4 & 2 & 2.8 & Family & FR & $\%$ \\
\hline 2 & Acaia decurrens Willd. & Dikerens & Fabaceae & $\mathrm{T}$ & 3 & 1.1 & 13 & 18.2 & Aloeaceae & 6 & 2.3 \\
\hline 3 & Acacia etbaica Schweinf. & Seraw & Fabaceae & $\mathrm{T}$ & 16 & 6.0 & 108 & 151.2 & Anacardiaceae & 8 & 3.0 \\
\hline 4 & Acacia lahai Benth. & Lahai & Fabaceae & $\mathrm{T}$ & 2 & 0.8 & 8 & 11.2 & Apocynaceae & 13 & 4.9 \\
\hline 5 & Acacia saligna (Labill.) Wendl. & Acacha & Fabaceae & $\mathrm{T}$ & 6 & 2.3 & 59 & 82.6 & Asclepiadaceae & 1 & 0.4 \\
\hline 6 & Acokanthera schimpri (A. DC.) Schweinf. & Mebti'a & Apocynaceae & $\mathrm{T}$ & 4 & 1.5 & 28 & 39.2 & Berberidaceae & 1 & 0.4 \\
\hline 7 & Acacia seyal Delile & Tsa'eda che'a & Fabaceae & $\mathrm{T}$ & 15 & 5.6 & 52 & 72.8 & Buddleiaceae & 1 & 0.4 \\
\hline 8 & Aloe vera (A. barbadensis) (L.) Burm. f. & E'are & Aloeaceae & $\mathrm{S}$ & 6 & 2.3 & 101 & 141.4 & Cactaceae & 1 & 0.4 \\
\hline 9 & Becium grandiflorum (Lam.) Pic. Serm. & Tebeb & Lamiaceae & $\mathrm{S}$ & 23 & 8.6 & 224 & 313.6 & Capparidaceae & 2 & 0.8 \\
\hline 10 & Berberis holstii Engl. & Zinkila & Berberidaceae & $\mathrm{S}$ & 1 & 0.4 & 2 & 2.8 & Celastraceae & 34 & 12.8 \\
\hline 11 & Buddleja polystachya Fresen. & Metere & Loganiaceae & S & 3 & 1.1 & 3 & 4.2 & Combretaceae & 3 & 1.1 \\
\hline 12 & Calpurinia aurea (Aiton) Benth. & Htsawts & Fabaceae & $\mathrm{S}$ & 10 & 3.8 & 50 & 70 & Cupressaceae & 26 & 9.8 \\
\hline 13 & Cadaba farinosa Forssk. & Taum chena & Capparidaceae & $\mathrm{S}$ & 2 & 0.8 & 6 & 8.4 & Ebenaceae & 33 & 12.4 \\
\hline 14 & Carissa spinarum $\mathrm{L}$. & Agam & Apocynaceae & $\mathrm{S}$ & 9 & 3.4 & 14 & 19.6 & Ericaceae & 1 & 0.4 \\
\hline 15 & Leucas oligocephala Hook. f. & Swakerni & Labiatae & $\mathrm{S}$ & 3 & 1.1 & 40 & 56 & Euphorbiaceae & 5 & 1.9 \\
\hline 16 & Croton macrostachyus Hochst. ex Delile & Tanbuque & Euphorbiaceae & $\mathrm{T}$ & 2 & 0.8 & 2 & 2.8 & Fabaceae & 55 & 20.7 \\
\hline 17 & Cupressus lusitanica Mill. & Tsihidi ferengi & Cupressaceae & $\mathrm{T}$ & 4 & 1.5 & 21 & 29.4 & Flacourtiaceae & 1 & 0.4 \\
\hline 18 & Diospyros abyssinica(Hiern) F. White & Kumel a'awaf & Ebenaceae & $\mathrm{T}$ & 2 & 0.8 & 2 & 2.8 & Lamiaceae & 23 & 8.6 \\
\hline 19 & Diplostigma canescens K. Schum. & Halengi & Asclepiadaceae & $\mathrm{S}$ & 1 & 0.4 & 2 & 2.8 & Loganiaceae & 3 & 1.1 \\
\hline 20 & $\begin{array}{l}\text { Dichrostachys cinerea (L.) Wight \& } \\
\text { Arn. }\end{array}$ & Gonnok & Fabaceae & $\mathrm{S}$ & 1 & 0.4 & 2 & 2.8 & Loranthaceae & 1 & 0.4 \\
\hline 21 & Dovyalis abyssinica (A. Rich.) Warb. & Aihada & Flacourtiaceae & $\mathrm{S}$ & 1 & 0.4 & 1 & 1.4 & Malvaceae & 1 & 0.4 \\
\hline 22 & Dodonaea angustifolia L. f. & Tahsos & Sapindaceae & $\mathrm{S}$ & 14 & 5.3 & 393 & 550.2 & Myrtaceae & 15 & 5.6 \\
\hline 23 & Erica arborea L. & Shanto & Ericaceae & $\mathrm{S}$ & 1 & 0.4 & 1 & 1.4 & Oleaceae & 9 & 3.4 \\
\hline 24 & Euphorbia abyssinica J.F. Gmel. & Kolkual & Euphorbiaceae & $\mathrm{T}$ & 3 & 1.1 & 6 & 8.4 & Oliniaceae & 3 & 1.1 \\
\hline 25 & Eucalyptus camaldulensis Dehnh. & Keyh bahr zaf & Myrtaceae & $\mathrm{T}$ & 10 & 3.8 & 46 & 64.4 & Polygonaceae & 2 & 0.8 \\
\hline 26 & Eucalyptus globulus Labill. & Tsa'eda bahr zaf & Myrtaceae & $\mathrm{T}$ & 5 & 1.9 & 12 & 16.8 & Proteaceae & 1 & 0.4 \\
\hline 27 & Euclea racemosa L. & Kuli'aw & Ebenaceae & $\mathrm{S}$ & 31 & 11.7 & 278 & 389.2 & Rosaceae & 1 & 0.4 \\
\hline 28 & Grewia ferruginea Hochst. ex A. Rich. & Tsimkuya & Tiliaceae & $\mathrm{S}$ & 2 & 0.8 & 4 & 5.6 & Sapindaceae & 14 & 5.3 \\
\hline 29 & Grevillea robusta A. Cunn. ex R. Br. & Gravila & Proteaceae & $\mathrm{T}$ & 1 & 0.4 & 1 & 1.4 & Tiliaceae & 2 & 0.8 \\
\hline 30 & Juniperus procera Hochst. ex Endl. & Tsihidi habesha & Cupressaceae & $\mathrm{T}$ & 22 & 8.3 & 96 & 134.4 & Total & 266 & 100 \\
\hline 31 & $\begin{array}{l}\text { Maytenus arbutifolia (Hochst. ex A. } \\
\text { Rich.) R. Wilczek }\end{array}$ & Atat & Celastraceae & $\mathrm{S}$ & 32 & 12.0 & 120 & 168 & & & \\
\hline 32 & Maytenus senegalensis (Lam.) Exell & Argudi & Celastraceae & $\mathrm{T}$ & 2 & 0.8 & 9 & 12.6 & & & \\
\hline 33 & Nuxia congesta R. Br. ex Fresen. & Atkaro & Buddleiaceae & $\mathrm{T}$ & 1 & 0.4 & 1 & 1.4 & & & \\
\hline 34 & Olea europaea L. & Awli'a & Oleaceae & $\mathrm{T}$ & 9 & 3.4 & 26 & 36.4 & & & \\
\hline 35 & Olinia rochetiana A. Juss. & Shigmesrhi & Oliniaceae & $\mathrm{S}$ & 3 & 1.1 & 14 & 19.6 & & & \\
\hline 36 & Opuntia ficus indica (L.) Mill. & Beles & Cactaceae & $\mathrm{S}$ & 1 & 0.4 & 5 & 7 & & & \\
\hline 37 & Osyris quadripartita Salzm. ex Decne. & Kerets & Loranthaceae & $\mathrm{T}$ & 1 & 0.4 & 1 & 1.4 & & & \\
\hline 38 & Rhus glutinosa Hochst. ex A. Rich. & Mengi & Anacardiaceae & $\mathrm{T}$ & 5 & 1.9 & 8 & 11.2 & & & \\
\hline 39 & Rhus retinorrhoea Steud. ex A. Rich. & Teta'alo & Anacardiaceae & $\mathrm{T}$ & 3 & 1.1 & 5 & 7 & & & \\
\hline 40 & Rosa abyssinica $\mathrm{R} . \mathrm{Br}$. & Konteftefe & Rosaceae & $\mathrm{S}$ & 1 & 0.4 & 1 & 1.4 & & & \\
\hline 41 & Rumex nervosus Vahl & Hakot & Polygonaceae & $\mathrm{S}$ & 2 & 0.8 & 6 & 8.4 & & & \\
\hline 42 & Senna singueana (Delile) Lock & Hambhambo & Fabaceae & $\mathrm{S}$ & 2 & 0.8 & 3 & 4.2 & & & \\
\hline & Total & & & & 266 & 100 & 1776 & 2486.4 & & & \\
\hline
\end{tabular}


Appendix 7. AB, DE, FR, LF, trees and shrubs of woody plants in less than 10 age $(\mathrm{P}=0.000)$

\begin{tabular}{|c|c|c|c|c|c|c|c|c|c|c|c|}
\hline R.no & Plant species in $<10$ years old & Vernacular name & Family & LF & FR & $\%$ & $\mathrm{AB}$ & $\mathrm{DE}$ & \multicolumn{3}{|c|}{ Family frequency } \\
\hline 1 & Acacia decurrens Willd. & Dikerens & Fabaceae & $\mathrm{T}$ & 4 & 2.4 & 13 & 24.7 & Family & FR & $\%$ \\
\hline 2 & Acacia etbaica Schweinf. & Seraw & Fabaceae & $\mathrm{T}$ & 15 & 9.0 & 138 & 262.2 & Aloeaceae & 4 & 2.4 \\
\hline 3 & Acacia seyal Delile & Tsa'eda che'a & Fabaceae & $\mathrm{T}$ & 10 & 6.0 & 30 & 57.0 & Apocynaceae & 2 & 1.2 \\
\hline 4 & $\begin{array}{l}\text { Aloe vera (A. barbadensis) (L.) } \\
\text { Burm. f. }\end{array}$ & E'are & Aloeaceae & $\mathrm{S}$ & 4 & 2.4 & 7 & 13.3 & Celastraceae & 16 & 9.6 \\
\hline 5 & $\begin{array}{l}\text { Becium grandiflorum (Lam.) } \\
\text { Pic. Serm. }\end{array}$ & Tebeb & Lamiaceae & $\mathrm{S}$ & 36 & 21.7 & 325 & 617.5 & Combretaceae & 3 & 1.8 \\
\hline 6 & Calpurinia aurea (Aiton) Benth & Htsawts & Fabaceae & $\mathrm{S}$ & 4 & 2.4 & 21 & 39.9 & Cupressaceae & 14 & 8.4 \\
\hline 7 & Carissa spinarum $\mathrm{L}$. & Agam & Apocynaceae & S & 2 & 1.2 & 2 & 3.8 & Ebenaceae & 33 & 19.9 \\
\hline 8 & Leucas oligocephala Hook. f. & Swakerni & Labiatae & S & 3 & 1.8 & 15 & 28.5 & Euphorbiaceae & 8 & 4.8 \\
\hline 9 & Dodonaea angustifolia L. f. & Tahsos & Sapindaceae & $\mathrm{S}$ & 1 & 0.6 & 1 & 1.9 & Fabaceae & 37 & 22.3 \\
\hline 10 & $\begin{array}{l}\text { Euphorbia abyssinica J.F. } \\
\text { Gmel. }\end{array}$ & kolqual & Euphorbiaceae & $\mathrm{T}$ & 8 & 4.8 & 25 & 47.5 & Lamiaceae & 38 & 22.9 \\
\hline 11 & Euclea racemosa $\mathrm{L}$. & Kuli'aw & Ebenaceae & $\mathrm{S}$ & 33 & 19.9 & 293 & 556.7 & Oliniaceae & 1 & 0.6 \\
\hline 12 & $\begin{array}{l}\text { Juniperus procera } \text { Hochst. ex } \\
\text { Endl. }\end{array}$ & Tsihidi habesha & Cupressaceae & $\mathrm{T}$ & 14 & 8.4 & 76 & 144.4 & Polygonaceae & 9 & 5.4 \\
\hline 13 & $\begin{array}{l}\text { Maytenus arbutifolia (Hochst. } \\
\text { ex A. Rich.) R. Wilczek }\end{array}$ & Atat & Celastraceae & $\mathrm{S}$ & 11 & 6.6 & 40 & 76.0 & Sapindaceae & 1 & 0.6 \\
\hline 14 & $\begin{array}{l}\text { Maytenus senegalensis (Lam.) } \\
\text { Exell }\end{array}$ & Argudi & Celastraceae & $\mathrm{T}$ & 5 & 3.0 & 9 & 17.1 & Total & 166 & 100.0 \\
\hline 15 & Olinia rochetiana A. Juss & Beye/Shimesrhi & Oliniaceae & $\mathrm{S}$ & 1 & 0.6 & 14 & 26.6 & & & \\
\hline 16 & Otostegia integrifolia Benth. & Mesaguh/chi'andog & Lamiaceae & S & 3 & 1.8 & 16 & 30.4 & & & \\
\hline 17 & Rumex nervosus Vahl & Hakot & Polygonaceae & $\mathrm{S}$ & 8 & 4.8 & 29 & 55.1 & & & \\
\hline \multirow[t]{2}{*}{18} & Senna singueana (Delile) Lock & Hambhambo & Fabaceae & $\mathrm{S}$ & 4 & 2.4 & 12 & 22.8 & & & \\
\hline & Total & & & & 166 & 100 & 1066 & 2025.4 & & & \\
\hline
\end{tabular}

Appendix 8. AB, DE, FR, LF, trees and shrubs of woody plants in between 10 and 20 age $(\mathrm{P}=0.000)$

\begin{tabular}{|c|c|c|c|c|c|c|c|c|c|c|c|}
\hline R.no & Plant species in between $10 \& 20$ age & Vernacular name & Family & LF & FR & $\%$ & $\mathrm{AB}$ & $\mathrm{DE}$ & \multicolumn{3}{|c|}{ Family frequency } \\
\hline 1 & Acaia decurrens Willd. & Dikerens & Fabaceae & $\mathrm{T}$ & 9 & 3.9 & 46 & 87.4 & Family & FR & $\%$ \\
\hline 2 & Acacia lahai Benth. & Lahai & Fabaceae & $\mathrm{T}$ & 6 & 2.6 & 27 & 51.3 & Aloeaceae & 2 & 0.9 \\
\hline 3 & Acacia saligna (Labill.) Wendl. & Acacha & Fabaceae & $\mathrm{T}$ & 21 & 9.1 & 179 & 340.1 & Anacardiaceae & 1 & 0.4 \\
\hline 4 & Acacia seyal Delile & Tsa'eda che'a & Fabaceae & $\mathrm{T}$ & 12 & 5.2 & 52 & 98.8 & Celastraceae & 35 & 15.2 \\
\hline 5 & Aloe vera (L.) Burm. f. & E'are & Aloeaceae & $\mathrm{S}$ & 2 & 0.9 & 5 & 9.5 & Cupressaceae & 35 & 15.2 \\
\hline 6 & $\begin{array}{l}\text { Becium grandiflorum (Lam.) Pic. } \\
\text { Serm. }\end{array}$ & Tebeb & Lamiaceae & $\mathrm{S}$ & 10 & 4.3 & 81 & 153.9 & Ebenaceae & 18 & 7.8 \\
\hline 7 & Calpurinia aurea (Aiton) Benth. & Htsawts & Fabaceae & S & 11 & 4.8 & 36 & 68.4 & Euphorbiaceae & 5 & 2.2 \\
\hline 8 & Clutia lanceolate Forssk. & Bokokot & Euphorbiaceae & $\mathrm{S}$ & 1 & 0.4 & 1 & 1.9 & Fabaceae & 71 & 30.7 \\
\hline 9 & $\begin{array}{l}\text { Croton macrostachyus Hochst. ex } \\
\text { Delile }\end{array}$ & Tambuque & Euphorbiaceae & $\mathrm{T}$ & 4 & 1.7 & 9 & 17.1 & Lamiaceae & 13 & 5.6 \\
\hline 10 & Cupressus lusitanica Mill. & Tsihidi ferenji & Cupressaceae & $\mathrm{T}$ & 4 & 1.7 & 16 & 30.4 & Myrtaceae & 29 & 12.6 \\
\hline 11 & $\begin{array}{l}\text { Dichrostachys cinerea (L.) Wight \& } \\
\text { Arn. }\end{array}$ & Gonnok & Fabaceae & $\mathrm{S}$ & 2 & 0.9 & 5 & 9.5 & Oleaceae & 1 & 0.4 \\
\hline 12 & Dodonaea angustifolia L. f. & Tahsos & Sapindaceae & S & 20 & 8.7 & 636 & 1208.4 & Proteaceae & 1 & 0.4 \\
\hline 13 & Eucalyptus camaldulensis Dehnh. & Keyh bahir zaf & Myrtaceae & $\mathrm{T}$ & 18 & 7.8 & 102 & 193.8 & Sapindaceae & 20 & 8.7 \\
\hline 14 & Eucalyptus globulus Labill. & Tsa'eda bahir zaf & Myrtaceae & $\mathrm{T}$ & 11 & 4.8 & 32 & 60.8 & Total & 231 & 100 \\
\hline 15 & Euclea racemose $\mathrm{L}$. & Kuli'aw & Ebenaceae & $\mathrm{S}$ & 18 & 7.8 & 195 & 370.5 & & & \\
\hline 16 & Grevillea robusta A. Cunn. ex R. Br. & Gravilia & Proteaceae & $\mathrm{T}$ & 1 & 0.4 & 4 & 7.6 & & & \\
\hline 17 & Juniperus procera Hochst. ex Endl. & Tsihidi habesha & Cupressaceae & $\mathrm{T}$ & 31 & 13.4 & 133 & 252.7 & & & \\
\hline 18 & $\begin{array}{l}\text { Maytenus arbutifolia (Hochst. ex A. } \\
\text { Rich.) R. Wilczek }\end{array}$ & Atat & Celastraceae & $\mathrm{S}$ & 32 & 13.9 & 169 & 321.1 & & & \\
\hline 19 & Maytenus senegalensis (Lam.) Exell & Argudi/kebkeb & Celastraceae & $\mathrm{T}$ & 3 & 1.3 & 4 & 7.6 & & & \\
\hline 20 & Olea europaea L. & Awli'a & Oleaceae & $\mathrm{T}$ & 1 & 0.4 & 2 & 3.8 & & & \\
\hline 21 & Otostegia integrifolia Benth. & Chi'andog & Lamiaceae & $\mathrm{S}$ & 3 & 1.3 & 7 & 13.3 & & & \\
\hline 22 & Rhus retinorrhoea Steud. ex A. Rich. & Teta'alo & Anacardiaceae & $\mathrm{T}$ & 1 & 0.4 & 1 & 1.9 & & & \\
\hline 23 & Senna singueana (Delile) Lock & Hambhambo & Fabaceae & $\mathrm{S}$ & 10 & 4.3 & 22 & 41.8 & & & \\
\hline & Total & & & & 231 & 100.0 & 1764 & 3351.6 & & & \\
\hline
\end{tabular}


Appendix 9. AB, DE, FR, LF, trees and shrubs of woody plants in between 20 and 30 age $(\mathrm{P}=0.007)$

\begin{tabular}{|c|c|c|c|c|c|c|c|c|c|c|c|}
\hline R.no & Plant species in between $20 \& 30$ age & Vernacular name & Family & $\mathrm{LF}$ & FR & $\%$ & $\mathrm{AB}$ & $\mathrm{DE}$ & Family fre & juency & \\
\hline 1 & $\begin{array}{l}\text { Abutilon longicuspe Hochst. ex A. } \\
\text { Rich. }\end{array}$ & Tsa'eda embwak & Malvaceae & $\mathrm{S}$ & 2 & 0.8 & 2 & 3.8 & Family & FR & $\%$ \\
\hline 2 & Acacia etbaica Schweinf. & Seraw & Fabaceae & $\mathrm{T}$ & 27 & 10.2 & 221 & 419.9 & Aloeaceae & 2 & 0.8 \\
\hline 3 & Acacia saligna (Labill.) Wendl. & Acacha & Fabaceae & $\mathrm{T}$ & 3 & 1.1 & 16 & 30.4 & Anacardiaceae & 18 & 6.8 \\
\hline 4 & $\begin{array}{l}\text { Acokanthera schimpri (A. DC.) } \\
\text { Schweinf. }\end{array}$ & Mebti'a & Apocynaceae & $\mathrm{T}$ & 3 & 1.1 & 7 & 13.3 & Apocynaceae & 16 & 6.0 \\
\hline 5 & Acacia seyal Delile & Tsa'eda cha'a & Fabaceae & $\mathrm{T}$ & 12 & 4.5 & 38 & 72.2 & Asclepiadaceae & 1 & 0.4 \\
\hline 6 & $\begin{array}{l}\text { Aloe vera (A. barbadensis) (L.) } \\
\text { Burm. f. }\end{array}$ & E'are & Aloeaceae & $\mathrm{S}$ & 2 & 0.8 & 9 & 17.1 & Berberidaceae & 1 & 0.4 \\
\hline 7 & $\begin{array}{l}\text { Becium grandiflorum (Lam.) Pic. } \\
\text { Serm. }\end{array}$ & Tebeb & Lamiaceae & $\mathrm{S}$ & 23 & 8.6 & 332 & 630.8 & Capparidaceae & 6 & 2.3 \\
\hline 8 & Berberis holstii Engl. & Zinkila & Berberidaceae & $\mathrm{S}$ & 1 & 0.4 & 2 & 3.8 & Celastraceae & 29 & 10.9 \\
\hline 9 & Calpurinia aurea (Aiton) Benth. & Htsawts & Fabaceae & $\mathrm{S}$ & 4 & 1.5 & 9 & 17.1 & Combretaceae & 9 & 3.4 \\
\hline 10 & Cadaba farinosa Forssk. & Taum chena & Capparidaceae & $\mathrm{S}$ & 6 & 2.3 & 15 & 28.5 & Cupressaceae & 8 & 3.0 \\
\hline 11 & Carissa spinarum $\mathrm{L}$. & Agam & Apocynaceae & $\mathrm{S}$ & 13 & 4.9 & 15 & 28.5 & Ebenaceae & 26 & 9.8 \\
\hline 12 & Leucas oligocephala Hook. f. & Swakerni & Labiatae & $\mathrm{S}$ & 9 & 3.4 & 91 & 172.9 & Euphorbiaceae & 4 & 1.5 \\
\hline 13 & $\begin{array}{l}\text { Croton macrostachyus Hochst. ex } \\
\text { Delile }\end{array}$ & Tanbuque & Euphorbiaceae & $\mathrm{T}$ & 4 & 1.5 & 10 & 19.0 & Fabaceae & 51 & 19.2 \\
\hline 14 & Cupressus lusitanica Mill. & Tsihidi ferengi & Cupressaceae & $\mathrm{T}$ & 4 & 1.5 & 14 & 26.6 & Flacourtiaceae & 3 & 1.1 \\
\hline 15 & Diplostigma canescens K. Schum. & Halengi & Asclepiadaceae & $\mathrm{S}$ & 1 & 0.4 & 2 & 3.8 & Lamiaceae & 23 & 8.6 \\
\hline 16 & Dodonaea angustifolia L. f. & Tahsos & Sapindaceae & $\mathrm{S}$ & 24 & 9.0 & 253 & 480.7 & Loranthaceae & 2 & 0.8 \\
\hline 17 & Eucalyptus camaldulensis Dehnh. & Keyh bahir zaf & Myrtaceae & $\mathrm{T}$ & 2 & 0.8 & 2 & 3.8 & Malvaceae & 2 & 0.8 \\
\hline 18 & Euclea racemose $\mathrm{L}$. & Kuli'aw & Ebenaceae & $\mathrm{S}$ & 26 & 9.8 & 161 & 305.9 & Myricaceae & 4 & 1.5 \\
\hline 19 & Grevillea robusta A. Cunn. ex R. Br. & Gravila & Proteaceae & $\mathrm{T}$ & 2 & 0.8 & 4 & 7.6 & Myrtaceae & 2 & 0.8 \\
\hline 20 & Juniperus procera Hochst. ex Endl. & Tshdi habesha & Cupressaceae & $\mathrm{T}$ & 4 & 1.5 & 9 & 17.1 & Oleaceae & 9 & 3.4 \\
\hline 21 & $\begin{array}{l}\text { Maytenus arbutifolia (Hochst. ex A. } \\
\text { Rich.) R. Wilczek }\end{array}$ & Atat & Celastraceae & $\mathrm{S}$ & 24 & 9.0 & 108 & 205.2 & Oliniaceae & 8 & 3.0 \\
\hline 22 & Maytenus senegalensis (Lam.) Exell & Argudi & Celastraceae & $\mathrm{T}$ & 5 & 1.9 & 7 & 13.3 & Phytolaccaceae & 4 & 1.5 \\
\hline 23 & Myrica salicifolia Hochst. ex A. Rich. & Nihibi & Myricaceae & $\mathrm{S}$ & 4 & 1.5 & 8 & 15.2 & Polygonaceae & 2 & 0.8 \\
\hline 24 & Olea europaea L. & Awli'a & Oleaceae & $\mathrm{T}$ & 9 & 3.4 & 21 & 39.9 & Proteaceae & 2 & 0.8 \\
\hline 25 & Olinia rochetiana A. Juss. & Shgmesrhi & Oliniaceae & $\mathrm{S}$ & 8 & 3.0 & 25 & 47.5 & Rhamnaceae & 5 & 1.9 \\
\hline 26 & Oncoba spinosa Forssk. & Eqot & Flacourtiaceae & $\mathrm{T}$ & 3 & 1.1 & 6 & 11.4 & Rubiaceae & 2 & 0.8 \\
\hline 27 & $\begin{array}{l}\text { Osyris quadripartite Salzm. ex } \\
\text { Decne. }\end{array}$ & Kerets & Loranthaceae & $\mathrm{T}$ & 2 & 0.8 & 2 & 3.8 & Sapindaceae & 24 & 9.0 \\
\hline 28 & Phytolacca dodecandra L'Hér. & Shimiti & Phytolaccaceae & $\mathrm{S}$ & 4 & 1.5 & 8 & 15.2 & Vitaceae & 3 & 1.1 \\
\hline 29 & $\begin{array}{l}\text { Psydrax schimperiana (A. Rich.) } \\
\text { Bridson }\end{array}$ & Zahak & Rubiaceae & $\mathrm{T}$ & 2 & 0.8 & 2 & 3.8 & Total & 266 & 100 \\
\hline 30 & Rhus glutinosa Hochst. ex A. Rich. & Mengi & Anacardiaceae & $\mathrm{T}$ & 13 & 4.9 & 16 & 30.4 & & & \\
\hline 31 & Rhamnus prinoids L'Hér. & Gesho & Rhamnaceae & $\mathrm{S}$ & 5 & 1.9 & 21 & 39.9 & & & \\
\hline 32 & Rhus retinorrhoea Steud. ex A. Rich. & Teta'alo & Anacardiaceae & $\mathrm{T}$ & 1 & 0.4 & 1 & 1.9 & & & \\
\hline 33 & $\begin{array}{l}\text { Rhoicissus tridentata (L. f.) Wild \& } \\
\text { R.B. Drumm. }\end{array}$ & Karshiro & Vitaceae & $\mathrm{S}$ & 3 & 1.1 & 6 & 11.4 & & & \\
\hline 34 & Rumex nervosus Vahl & Hakot & Polygonaceae & $\mathrm{S}$ & 2 & 0.8 & 5 & 9.5 & & & \\
\hline 35 & Schinus molle L. & Qundo berbere & Anacardiaceae & $\mathrm{T}$ & 4 & 1.5 & 6 & 11.4 & & & \\
\hline \multirow[t]{2}{*}{36} & Senna singueana (Delile) Lock & Hambhambo & Fabaceae & $\mathrm{S}$ & 5 & 1.9 & 12 & 22.8 & & & \\
\hline & Total & & & & 266 & 100.0 & 1466 & 2785.4 & & & \\
\hline
\end{tabular}


Appendix 10. AB, DE, FR, LF, trees and shrubs of woody plants in greater than 30 age $(\mathrm{P}=0.000)$

\begin{tabular}{|c|c|c|c|c|c|c|c|c|c|c|c|}
\hline R.no & Plant in greater than 30 years old & Vernacular name & Family & LF & FR & $\%$ & $\mathrm{AB}$ & $\mathrm{DE}$ & \multicolumn{3}{|c|}{ Family frequency } \\
\hline 1 & $\begin{array}{l}\text { Abutilon longicuspe Hochst. ex A. } \\
\text { Rich. }\end{array}$ & Tsa'eda embwak & Malvaceae & $\mathrm{S}$ & 5 & 1.5 & 8 & 15.2 & Family & FR & $\%$ \\
\hline 2 & Acacia etbaica Schweinf. & Seraw & Fabaceae & $\mathrm{T}$ & 10 & 3.0 & 80 & 152.0 & Acanthaceae & 1 & 0.3 \\
\hline 3 & $\begin{array}{l}\text { Acokanthera schimpri (A. DC.) } \\
\text { Schweinf. }\end{array}$ & Mebt'a & Apocynaceae & $\mathrm{T}$ & 8 & 2.4 & 92 & 174.8 & Aloeaceae & 8 & 2.4 \\
\hline 4 & Acacia seyal Delile & Tsa'eda che'a & Fabaceae & $\mathrm{T}$ & 32 & 9.8 & 103 & 195.7 & Anacardiaceae & 11 & 3.4 \\
\hline 5 & $\begin{array}{l}\text { Aloe vera }(\text { A. barbadensis) (L.) } \\
\text { Burm. f. }\end{array}$ & E'are & Aloeaceae & $\mathrm{S}$ & 8 & 2.4 & 142 & 269.8 & Apocynaceae & 19 & 5.8 \\
\hline 6 & $\begin{array}{l}\text { Becium grandiflorum (Lam.) Pic. } \\
\text { Serm. }\end{array}$ & Tebeb & Lamiaceae & $\mathrm{S}$ & 7 & 2.1 & 115 & 218.5 & Asteraceae & 5 & 1.5 \\
\hline 7 & Berberis holstii Engl. & Zinkila & Berberidaceae & $\mathrm{S}$ & 1 & 0.3 & 2 & 3.8 & Berberidaceae & 1 & 0.3 \\
\hline 8 & Buddleja polystachya Fresen. & Metere & Loganiaceae & $\mathrm{S}$ & 9 & 2.7 & 10 & 19.0 & Bignoniaceae & 5 & 1.5 \\
\hline 9 & Calpurinia aurea (Aiton) Benth. & Htsawts & Fabaceae & $\mathrm{S}$ & 22 & 6.7 & 111 & 210.9 & Boraginaceae & 2 & 0.6 \\
\hline 10 & Cadaba farinosa Forssk. & T'aum chena & Capparidaceae & $\mathrm{S}$ & 1 & 0.3 & 1 & 1.9 & Buddleiaceae & 6 & 1.8 \\
\hline 11 & Carissa spinarum $\mathrm{L}$. & Agam & Apocynaceae & $\mathrm{S}$ & 11 & 3.4 & 15 & 28.5 & Cactaceae & 7 & 2.1 \\
\hline 12 & Leucas oligocephala Hook. f. & Swakerni & Labiatae & $\mathrm{S}$ & 5 & 1.5 & 64 & 121.6 & Capparidaceae & 1 & 0.3 \\
\hline 13 & Cordia africana Lam. & Aqui & Boraginaceae & $\mathrm{T}$ & 2 & 0.6 & 2 & 3.8 & Celastraceae & 17 & 5.2 \\
\hline 14 & $\begin{array}{l}\text { Croton macrostachyus Hochst. ex } \\
\text { Delile }\end{array}$ & Tanbuque & Euphorbiaceae & $\mathrm{T}$ & 9 & 2.7 & 14 & 26.6 & Combretaceae & 5 & 1.5 \\
\hline 15 & $\begin{array}{l}\text { Diospyros abyssinica (Hiern) F. } \\
\text { White }\end{array}$ & Kumel a'awaf & Ebenaceae & $\mathrm{T}$ & 2 & 0.6 & 2 & 3.8 & Cupressaceae & 16 & 4.9 \\
\hline 16 & $\begin{array}{l}\text { Dovyalis abyssinica (A. Rich.) } \\
\text { Warb. }\end{array}$ & Aihada & Flacourtiaceae & $\mathrm{S}$ & 3 & 0.9 & 3 & 5.7 & Ebenaceae & 19 & 5.8 \\
\hline 17 & Dodonaea angustifolia L. f. & Tahsos & Sapindaceae & $\mathrm{S}$ & 10 & 3.0 & 170 & 323.0 & Ericaceae & 2 & 0.6 \\
\hline 18 & Ekebergia capensis Sparrm. & Kot & Meliaceae & $\mathrm{T}$ & 4 & 1.2 & 10 & 19.0 & Euphorbiaceae & 14 & 4.3 \\
\hline 19 & Erica arborea L. & Shanto & Ericaceae & $\mathrm{S}$ & 2 & 0.6 & 2 & 3.8 & Fabaceae & 68 & 20.7 \\
\hline 20 & Euphorbia abyssinica J.F. Gmel. & Kolkual & Euphorbiaceae & $\mathrm{T}$ & 5 & 1.5 & 16 & 30.4 & Flacourtiaceae & 7 & 2.1 \\
\hline 21 & Eucalyptus camaldulensis Dehnh. & Keyh bahr zaf & Myrtaceae & $\mathrm{T}$ & 17 & 5.2 & 87 & 165.3 & Lamiaceae & 7 & 2.1 \\
\hline 22 & Eucalyptus globulus Labill. & Tsa'eda bahr zaf & Myrtaceae & $\mathrm{T}$ & 6 & 1.8 & 26 & 49.4 & Loganiaceae & 9 & 2.7 \\
\hline 23 & Euclea racemosa L. & Kuli'aw & Ebenaceae & $\mathrm{S}$ & 17 & 5.2 & 200 & 380.0 & Malvaceae & 5 & 1.5 \\
\hline 24 & Ficus vasta Forssk. & Da'aro & Moraceae & $\mathrm{T}$ & 2 & 0.6 & 2 & 3.8 & Meliaceae & 4 & 1.2 \\
\hline 25 & $\begin{array}{l}\text { Grewia ferruginea Hochst. ex A. } \\
\text { Rich. }\end{array}$ & Tsimkuya & Tiliaceae & $\mathrm{S}$ & 3 & 0.9 & 6 & 11.4 & Moraceae & 3 & 0.9 \\
\hline 26 & Juniperus procera Hochst. ex Endl. & Tsihidi habesha & Cupressaceae & $\mathrm{T}$ & 16 & 4.9 & 38 & 72.2 & Myricaceae & 4 & 1.2 \\
\hline 27 & $\begin{array}{l}\text { Justicia schimperiana (Hochst. ex } \\
\text { Nees) T. Anderson }\end{array}$ & Shim'aya & Acanthaceae & $\mathrm{S}$ & 1 & 0.3 & 1 & 1.9 & Myrtaceae & 23 & 7.0 \\
\hline 28 & $\begin{array}{l}\text { Maytenus arbutifolia (Hochst. ex A. } \\
\text { Rich.) R. Wilczek }\end{array}$ & Atat & Celastraceae & $\mathrm{S}$ & 14 & 4.3 & 47 & 89.3 & Oleaceae & 19 & 5.8 \\
\hline 29 & Maytenus senegalensis (Lam.) Exell & Argudi & Celastraceae & $\mathrm{T}$ & 3 & 0.9 & 5 & 9.5 & Oliniaceae & 2 & 0.6 \\
\hline 30 & Morus alba $\mathrm{L}$. & Yferenj injori & Moraceae & $\mathrm{T}$ & 1 & 0.3 & 1 & 1.9 & Phytolaccaceae & 3 & 0.9 \\
\hline 31 & $\begin{array}{l}\text { Myrica salicifolia Hochst. ex A. } \\
\text { Rich. }\end{array}$ & Nihibi & Myricaceae & $\mathrm{S}$ & 4 & 1.2 & 8 & 15.2 & Pittosporaceae & 1 & 0.3 \\
\hline 32 & Nuxia congesta $\mathrm{R}$. Br. ex Fresen. & Atkaro & Buddleiaceae & $\mathrm{T}$ & 6 & 1.8 & 8 & 15.2 & Rhamnaceae & 4 & 1.2 \\
\hline 33 & Olea europaea L. & Awli'a & Oleaceae & $\mathrm{T}$ & 19 & 5.8 & 49 & 93.1 & Rosaceae & 8 & 2.4 \\
\hline 34 & Olinia rochetiana A. Juss. & Shigmesrhi & Oliniaceae & $\mathrm{S}$ & 2 & 0.6 & 21 & 39.9 & Salicaceae & 5 & 1.5 \\
\hline 35 & Oncoba spinosa Forssk. & Eqot & Flacourtiaceae & $\mathrm{T}$ & 4 & 1.2 & 12 & 22.8 & Sapindaceae & 10 & 3.0 \\
\hline 36 & Opuntia ficus indica (L.) Mill. & Beles & Cactaceae & $\mathrm{S}$ & 7 & 2.1 & 65 & 123.5 & Tiliaceae & 3 & 0.9 \\
\hline 37 & Phytolacca dodecandra L'Hér. & Shimiti & Phytolaccaceae & $\mathrm{S}$ & 3 & 0.9 & 5 & 9.5 & Vitaceae & 4 & 1.2 \\
\hline 38 & Pittosporum viridiflorum Sims & Chequente & Pittosporaceae & $\mathrm{T}$ & 1 & 0.3 & 3 & 5.7 & Total & 328 & 100 \\
\hline 39 & Prunus africana (Hook. f.) Kalkman & Tikur incheti & Rosaceae & $\mathrm{T}$ & 5 & 1.5 & 20 & 38.0 & & & \\
\hline 40 & Rhus glutinosa Hochst. ex A. Rich. & Mengi & Anacardiaceae & $\mathrm{T}$ & 2 & 0.6 & 6 & 11.4 & & & \\
\hline 41 & Rhamnus prinoids L'Hér. & Gesho & Rhamnaceae & $\mathrm{S}$ & 4 & 1.2 & 25 & 47.5 & & & \\
\hline 42 & $\begin{array}{l}\text { Rhus retinorrhoea Steud. ex A. } \\
\text { Rich. }\end{array}$ & Teta'alo & Anacardiaceae & $\mathrm{T}$ & 5 & 1.5 & 9 & 17.1 & & & \\
\hline 43 & $\begin{array}{l}\text { Rhoicissus tridentata (L. f.) Wild \& } \\
\text { R.B. Drumm. }\end{array}$ & Karshiro & Vitaceae & $\mathrm{S}$ & 4 & 1.2 & 12 & 22.8 & & & \\
\hline 44 & Rosa abyssinica R. Br. & Konteftefe & Rosaceae & $\mathrm{S}$ & 3 & 0.9 & 6 & 11.4 & & & \\
\hline 45 & $\begin{array}{l}\text { Salix mucronata }(S . \text { subserrata) } \\
\text { Thunb. }\end{array}$ & Kwaa & Salicaceae & $\mathrm{T}$ & 5 & 1.5 & 17 & 32.3 & & & \\
\hline 46 & Schinus molle L. & Qundo berbere & Anacardiaceae & $\mathrm{T}$ & 4 & 1.2 & 14 & 26.6 & & & \\
\hline 47 & Senna singueana (Delile) Lock & Hambhambo & Fabaceae & $\mathrm{S}$ & 4 & 1.2 & 19 & 36.1 & & & \\
\hline 48 & Stereospermum kunthianum Cham. & Argzana & Bignoniaceae & $\mathrm{T}$ & 5 & 1.5 & 13 & 24.7 & & & \\
\hline 49 & Vernonia amygdalina Delile & Grawa & Asteraceae & $\mathrm{T}$ & 5 & 1.5 & 15 & 28.5 & & & \\
\hline & Total & & & & 328 & 100 & 1702 & 3233.8 & & & \\
\hline
\end{tabular}




\title{
ВОССТАНОВЛЕНИЕ НАРУШЕННЫХ ЗАСУШЛИВЫХ ЗЕМЕЛЬ ПУТЕМ ИЗЪЯТИЯ ИХ ИЗ ХОЗЯЙСТВЕННОЙ ДЕЯТЕЛЬНОСТИ, ПОВЫШАЮЩЕГО РАЗНООБРАЗИЕ ДРЕВЕСНЫХ ВИДОВ И ПОЧВЕННОЕ ПИТАНИЕ, В ВЫСОКОГОРЬЯХ ТИГРАЯ, СЕВЕРНАЯ ЭФИОПИЯ
}

\author{
К. М. Гебремедихин, Е. Бирхане", Т. Тадессе, Х. Гбревахид \\ Университет Мэкэлле, Эфиопия \\ *e-mail:emiru.birhane@mu.edu.et,emiru.birhane.hizikiaz@nmbu.edu.et
}

\begin{abstract}
Изъятие пастбищных животных и посадок деревьев было одним из методов, используемых для восстановления деградированных земель в тропических полузасушливых областях. Изъятые земли могут способствовать вторичной сукцессии лесов, улучшая почвенные условия, привлекая агентов для распространения семян и изменяя микроклимат для развития подроста. В этой статье сравнивается разнообразие древесных пород и химические свойства почв на участках изъятых из использования в разное время и на пастбищах на склонах разной экспозиции. Исследование было проведено в Северной Эфиопии на 12 участков, изъятых из использования, и на таком же количестве выпасаемых участков, расположенных в непосредственной близости, с четырьмя обработками и в трех повторностях. В ходе работы было исследовано 216 участков, из которых 108 находились на исключенных из хозяйственной деятельности участках и 108 - на общинных пастбищах. В каждой группе участков было выделено четыре класса по возрасту и три - по экспозиции склона. Данные о растительности были собраны на участках размером $100 \mathbf{м}^{2}$. Образцы почвы для определения ее физико-химических свойств были собраны из четырех углов и центра участков размером $5 \times 5$ м, которые находились внутри участков размером $10 \times 10$ м. В общей сложности был зарегистрирован 61 вид древесных растений из 41 семейства. Разнообразие и видовое богатство были выше на участках, изъятых из сельскохозяйственной деятельности, чем на пастбищах. Среди неиспользуемых участков эти параметры были выше на тех, которые были изъяты из хозяйственной деятельности более 30 лет назад и которые расположены у подножий склонов. Пастбища, недавно изъятые из пользования участки и расположенные на вершине склонов показали наиболее низкие значения этих параметров. Химические свойства почвы были значительно благоприятнее для растительности на изъятых из пользования участках, а среди них - на участках, имеющих самый большой возраст и расположенных у подножия склонов (за исключением содержания фосфора) по сравнению со значениями этих показателей на пастбищах, на недавно изъятых из пользования участках и расположенных на верхних частях склонов. Таким образом, изымаемые из хозяйственного использования участки играют важную роль в повышении разнообразия древесных пород и улучшения химических свойств почвы в засушливых областях.
\end{abstract}

Ключевые слова: изъятые из хозяйственной деятельности участки, разнообразие древесных растений, химические свойства почвы, экспозиция склона 